\title{
Proteção contra produtos defeituosos: das origens ao MERCOSUL
}

\author{
Adalberto Lasqualotto
}

\section{Introdução}

12 marginal inexorável da indústria. Com a expansão fabril, revelou-se a inadequação do direito então posto nos países em processo de industrialização para assegurar a reparação dos danos sofridos pelos usuários, destinatários naturais dos bens que saíam das fábricas. Eram países essencialmente liberais, com regimes de responsabilidade civil que exigiam a prova da culpa como requisito da indenização, prova a ser constituída em juízo pelo lesado. As dificuldades na feitura dessa prova, decorrentes em grande parte do desconhecimento do processo industrial e da crescente automação, que nublava a imputação do fato lesivo a um autor determinado, conduziram a linha evolutiva do direito para a superação de limites, com o fim de favorecer a reparação às vítimas.

Os expedientes de que os juristas lançaram mão apresentaram inicialmente dois vetores: a extensão das garantias contratuais e a criação de responsabilidades extracontratuais. No âmbito contratual, foi rompida a relatividade do contrato para alcançar o fabricante, com quem o lesado normalmente

não tinha vínculo, pois adquirira o produto causador do dano de um intermediário. As garantias contratuais por si eram, porém, insuficientes, porque são classicamente voltadas para assegurar a utilidade do produto nada provendo quanto à segurança do usuário. No âmbito extracontratual, a culpa opu nha-se como óbice para o alcance da indenização correspondente aos danos pessoais. A evolução consistiu em presumir a culpa do fabricante, com a instituição de uma responsabilidade de caráter delitual mais rígida do que $o$ ato ilícito comum.

A evolução dessa responsabilidade pode ser percebida no common law, de modo especial nos precedentes ingleses e norte-americanos, e nos países continentais europeus de tradição romana.

Com a formação da Comunidade Econômica Européia, os sistemas common law e civil law convergiram para uma normatividade básica, que se expressou na Diretiva que trata da matéria. Já então havia amadurecido a idéia de que a responsabilidade civil do fabricante de um produto defeituoso lhe deve ser imputada em razão do risco que ele cria para

" Mestre em Direito Civil pela UFRGS. Doutorando na mesma Universidade. Trabalho apresentado para aquisição dos créditos correspondentes à disciplina "Direito do Consumidor no Mercosul", sob a orientação da Prof " $\mathrm{Dr}^{\mathrm{a}}$ Cláudia Lima Marques. 
terceiros, não de culpa, e independentemente da existência de vínculo contratual direto com a vítima.

O Brasil, país que se adiantou na América do Sul em legislar de modo abrangente sobre defesa do consumidor, recepcionou essas influências no Código editado em 1990, sob inspiração constitucional. Com o processo de formação do Mercosul em andamento, os demais paises do bloco também editaram leis ao mesmo respeito, mas ainda está distante o ponto ideal de uma normativa comum, no molde europeu.

O presente trabalho volta-se, num primeiro plano, para o exame das origens da evolução do direito em matéria de proteção contra produtos defeituosos e, logo em seguida, para o panorama do Mercosul. Restringe-se aos defeitos que ameaçam a segurança e a integridade física dos consumidores, sem ingressar no trato da proteção dos interesses econômicos, versados no CDC sob a rubrica de vícios. Também não se detém na disciplina paralela que diz respeito ao defeito dos serviços.

\section{Responsabilidade Civil por produtos defeituosos: a for- mação de um Patrimônio Ju- rídico}

A historiografia da proteção jurídica contra produtos defeituosos registra a contribuição paralela das duas famílias de direito hegemônicas no mundo ocidental, que convergiram para a formação de uma cultura que se universalizou. No common law e no direito norte-americano, os precedentes que delinearam o perfil da responsabilidade civil dos fabricantes foram surgindo pari passu com o desenvolvimento indus trial. Na Europa continental, um grande labor doutrinário e também jurisprudencial foi vencendo as barreiras impostas pelo positivismo jurídico. A formação da Comunidade Européia propiciou a fusão dessas experiências, resultante na Diretiva de ${ }^{\circ}$ 374 , de 1985

A razão que gestou a evolução das idéias na Europa e nos Estados Unidos nos alvores do século $X X$ se fez presente em outros quadrantes do globo, por efeito da propagação da indústria. Esses países, em desenvolvimento econômico mais atrasado, se beneficiaram da inspiração do modelo existente, implantando por via legislativa o resultado final do apontado processo histórico- jurídico.

\subsection{Vias de Proteção Contra-tual e Delitual}

As tradicionais fontes romanas do direito, o contrato e o delito, alicerçaram os sistemas jurídicos ocidentais. Particularmente na família romano-germânico, a codificação deu rigidez a essa dualidade, vencida pela evidência da sua inadequação a novos tempos e pelo aporte de idéias mais consentâneas com as realidades emergentes de uma sociedade em franca evolução. Os sistemas de civil law e commom law culminaram em idênticas conclusões: a ultrapassagem dos efeitos dos contratos limitadamente às partes e a superação da culpa como fundamento delitual, imputando ao fabricante a responsabilidade de indenizar os danos causados por defeitos dos seus produtos com base em garantias implícitas e no risco inerente à sua circulação.
2.1.1. Modificações na eficácia dos contratos e Responsabilidade Delitual no Common Law e no Direito Norte-Americano

2.1.1.1. Direito inglês. No direito inglês, a responsabilidade civil por produtos defeituosos não é um tema autonômico. Um produto pode ser considerado defeituoso sob dois aspectos: materialmente perigoso (dangerously defective), quando pode fazer mal à saúde humana; e substandard product (ou merely substandard) quando, não sendo perigoso, frustra a expectativa do consumidor por não atender à qualidade esperada. ${ }^{1}$

São indenizáveis danos econômicos primários (primary economic loss), que têm natureza contratual e compreendem a perda pèla compra da coisa e os eventuais lucros cessantes se, por exemplo, o comprador era um comerciante que tinha intenção de revender o produto adquirido. Também podem ser indenizados danos indiretos (consequential damages), como dano à propriedade, se o produto danificou um bem do adquirente, e lucro cessante, se a periculosidade do produto afetou a saúde do adquirente, impedindo-o de trabalhar por algum tempo. Os danos indiretos são extracontratuais e se inscrevem no regime da responsabilidade por produtos defeituosos. ${ }^{2}$

O regime contratual é estrito. Se um homem compra para a sua mulher um ferro de passar e o produto, por defeito, causa dano a ela, a reparação não comporta uma demanda com base no contrato, porque a mulher é um terceiro em relação à compra e venda. Essa rigidez devese ao princípio privity of contract.
A não existência de contrato entre o fabricante e o consumidor foi obviada com a criação de cláusulas implícitas, que se fortaleceram em estatutos legais. O Sales of Goods Act, de 1893, dispôs que as mercadorias vendidas em gênero, seja a venda realizada pelo fabricante ou não, têm uma condição implícita de qualidade comercial (merchantable qualitiy). A mesma garantia foi estendida aos gêneros de abastecimento em 1973, no Supply of Goods Act, que definiu qualidade comercial como a aptidão para servir aos fins para os quais a mercadoria habitualmente é comprada. Segundo o mesmo estatuto, a garantia deve conservar-se, dentro de um limite razoável, se o comprador dá conhecimento ao vendedor de um uso especial que pretende fazer da mercadoria, diferente da sua função habitual, a menos que o comprador tenha desconsiderado a opinião contrária do vendedor. Esses statutes law derrogaram o princípio caveat emptor.

A responsabilidade extracontratual baseia-se em fatos típicos descritos como torts Não há uma cláusula geral de ilicitude. O tipo mais próximo do art. $159, \mathrm{CCB}$, é o tort of negligence. Nele se subsumem os casos de produtos defeituosos, mas também é aplicável o tort of breach of statutory duty, toda vez que a lei imponha um dever que deixa de ser observado. Um dever é exigível do fabricante quando tem previsão no Consumer Protection Act, de 1961 .

As normas penais desempenham um papel importante. Desde 1972 (Criminal Justice Act) os tribunais podem estipular de ofício uma indenização em favor da vítima do crime, que 
será posteriormente descontada da liquidação do dano, se houver ação indenizatória. Em alguns casos, que incluem os de produtos defeituosos, a vítima pode demandar a reparação pelo dano sofrido com base em strict liability do fabricante, pelo simples descumprimento do dever contido na norma penal, sem necessidade de debater a culpa e independentemente da existência de processo criminal, com base no Criminal Law Act, de 1967.

Alguns precedentes judiciais que se tornaram célebres mostram a marcha das idéias na definição da responsabilidade civil do fabricante no direito inglês.

No caso Winterbottom $v$. Wright (1843), um cocheiro sofreu acidente com a carruagem que dirigia. Apesar de haver defeito de produção, o pedido de indenização foi julgado improcedente porque fora formulado contra o produtor, com quem a vítima não tinha vínculo contratual. Prevaleceu o princípio privity of contract,${ }^{3}$ que foi superado à medida que os tribunais passaram a distinguir things dangerous "per se" de things dangereous because of negligent construction.

Essa diferença ficou assinalada no caso Longmeid v. Holliday (1851). Uma lâmpada defeituosa explodiu, causando queimaduras na esposa do comprador. $O$ tribunal negou a indenização porque uma lâmpada não constitui $a$ thing dangereous in itself. $\mathrm{O}$ argumento, todavia, abriu caminho para uma mudança de orientação, que culminou no caso McAlister (ou Donoghue) v. Stevenson (1932), conhecido como Snail's case. Duas senhoras se encontraram num café, onde uma delas pediu uma ginger beer. Depois de ingerir parte da bebida, a vítima notou no fundo da garrafa os restos de um ca-

${ }^{3} \mathrm{O}$ caso Winterbotton permaneceu durante muitos anos como uma espinha na garganta, expressão de W. Prosser apud BARROS LEÃES, L. G. P. de. A Responsabilidade do Fabricante pelo fato do produto. São Paulo:
Saraiva, 1987. p. 44.

${ }^{4}$ SPENCER, J. Op. cit. p. 123-124.

${ }^{5}$ BARROS LEÃES, L. G. P. de. Op. cit. p. 39

Revista da Faculdade de Direito da UFRGS, v. 20, Outubro/2001 cance da responsabilidade do fabricante. Em seu voto, Lord Atkin afirmou que "o fabricante que vende seus produtos prevendo que eles chegarão ao consumidor definitivo no mesmo estado em que saíram da fábrica, sem possibilidade de exame intermediário, e verificando-se que a falta de cuidados razoáveis na prepara- ção e na apresentação dos produtos ocasionará um dano à vida ou à propriedade do consumidor, assume frente a ele um dever legal de adotar tais cuidados". ${ }^{6}$ A responsabilidade especial do fabricante está ligada ao consumo do produto. Se a mercadoria é destinada a um agente econômico intermediário a regra não é a mesma, aplicando-se preceitos comuns. A diferença de regime ficou assinalada no caso Holmes v. Ashford (1950), que tratava de um produto experimental.?

A inversão do ônus da prova veio no caso Grant v. New Australian Knitting Mills (1936). Um cidadão adquiriu um par de calças de lã, em cujo estágio inicial de produção entrava sulfito. Essa substância química permaneceu na calça mesmo após as primeiras lavagens e causou no adquirente uma grave dermatite, acompanhada de fortes dores e inabilitação para o trabalho por mais de um ano. A corte que decidiu o caso em favor do adquirente resolveu que era dispensável a prova da culpa específica de uma pessoa ou em que estágio da produção o defeito fora incorporado. A negligência decorre de uma presunção de existência de defeito, em conexão com todas as circunstâncias conhecidas, presunção que prevalece mesmo que o fabricante possa produzir prova em contrário. A corte fez aplicação da regra res ipsa loquitur, ${ }^{8}$ que considera como prova suficiente de culpa a falta de explicação do fabricante quando a coisa é produzida sob a sua vigilância ou de seus prepostos e verifica-se um evento danoso que não poderia desenrolar-se de

${ }^{6}$ Tradução livre da versão de GRUBER-MAGITOT, S. L'action du consummateur contre le fabricant d'um objet affecté par um vice cachê. Paris: Presses Universitaires de France, 1978. p. 89.

7 Conforme GRUBER-MAGITOT, S. Op. et loc. cit.

${ }^{8}$ Regra que fora definida no caso Scott v. London \& Saint Katherine Docks Co. (1865) 3 H. \& C. 596, apud SPENCER, J. Op. cit. p. 125

- A inversão do ônus da prova constitui uma prova absoluta de culpa, provando-se a negligência por meio das circunstâncias conhecidas. Daí porque a sede da responsabilidade por produtos defeituosos é o tort of negigence. 9 HENDERSON JR., J. A.; TWERSKI, A. D. Closing the american products liability frontier: the rejection of liability without defect. New York University Law Review, v. 66, n. 5, p. 1263-1331, Nov. 91 ordinário se no processo de fabricação tivesse havido a diligência devida. ${ }^{*}$ A prova de que o produto defeituoso é um fato excepcional, que discrepa de toda a normalidade da produção, não exonera o fabricante, pois a sua responsa-

2.1.1.2. Direito norte-americano. Nos Estados Unidos, o surto industrial subseqüente à Guerra Civil propiciou o começo da proteção aos checialmente invertendo ônus da prova para a inferência de negligência, bem como derrubaram barreiras contratuais, com de garantias. $^{9}$

A regra da relatividade do contrato fo quebrada pela primeira vez no caso Thomas $v$. Winchester (1852). Um veneno foi vendido como dadão chamado Thomas. Depois de ingerir poção, a mulher do adquirente passou mal e obteve reparação de danos do laboratório Winchester, fornecedor da farmácia, que etiquetara o produto erroneamente. $\mathrm{O}$ dever de produto inerentemente perigoso à saúde não se extinguiu frente ao farmacêutico, adquirente imediato de um produto destinado a uso por terceiros desavisados.

Em 1916, foi registrado o caso MacPherson v. Buick Motor Co. Tendo adquibilidade tem natureza de garantia. prejudicados por produtos defeituosos. As cortes norte-americanas construíram uma base cuidado do laboratório ao colocar no mercado 
rido um automóvel da marca Buick, MacPherson sofreu graves lesões em acidente causado por uma roda que se partiu por defeito de fabricação. O lesado propôs a ação indenizatória contra o fabricante, e não contra o vendedor. A pretensão foi acolhida pelo tribunal, que prescindiu da privity in contract e imputou um dever de diligência (duty of care) a quem fabrica qualquer produto capaz de colocar em perigo a vida ou a integridade física de outrem, quando feito negligentemente. $O$ dever de cuidado instituído no caso Thomas v. Winchester generalizou-se, tornando o fabricante responsável frente ao usuário final, se provada a negligência na fabricação e a periculosidade do produto.

A partir do caso MacPherson, o direito norte-americano formulou três diretrizes básicas para a responsabilidade civil do fabricante: a) em presença de um vínculo contratual, o fabricante responde nos amplos termos da obrigação de garantia (warranty); b) se o lesado é um terceiro sem vínculo contratual, é imputado um dever de cuidado (duty of care) ao fabricante, que passa a responder por negligência (negligence); c) a negligência, no entanto, tem que ser demonstrada pelo lesado, tornando-se freqüentemente uma prova diabólica. Daí a aplicação da regra res ipsa loquitur (a coisa fala por si mesma), um instrumento processual de inversão do ônus da prova. ${ }^{10}$

Uma nova perspectiva somente surgiu com o caso Henningsen v. Bloomfield Motors Inc., ${ }^{11}$ julgado em 1960 na Suprema Corte de New Jersey, que proclamou a responsabilidade solidária entre o fabricante de um automóvel e o seu revendedor, com base em implied warranty, uma garantia implícita no contrato de compra e venda. Os argumentos básicos foram que, numa sociedade de massa, as garantias de

${ }^{10}$ BARROS LEÃES, L. G. P.de. Op. cit. p. 45.

${ }^{11}$ Heningsen v. Bloomfield Motors Inc., 32 N.J. 358, 161 A.2d 69 (1960), apud WHITE, J. J.; SUMMERS, R. S Uniform Commercial Code. $3^{\mathrm{d}}$ ed. St. Paul, Minn.: West Publishing, 1988.

Revista da Faculdade de Direito da UFRGS, v. 20, Outubro/2001 vel pelo dano físico desse modo causado ao consumidor, ao usuário ou às suas coisas, se: a) o vendedor desenvolve atividade de venda do produto; b) é razoável esperar-se que o produto chegue ao usuário ou consumidor nas mesmas condições em que é posto à venda. 2) A regra anterior se aplica ainda que: a) o vendedor tenha empregado toda diligência possível na fabricação e na venda do produto; b) o usuário ou o consumidor não tenha adquirido o produto diretamente do vendedor nem tenha mantido com ele relação contratual".

A venda em questão é feita pelo fabricante ao comerciante no momento da colocação do produto no mercado. O fabricante assume uma responsabilidade especial, porque desperta no público a confiança de que a compra do produto poderá atender a uma necessidade. A responsabilidade é objetiva, sem excluir, todavia, a possibilidade de ser invocada a culpa. Examina-se a relação de causa e efeito entre a imperfeição técnica do produto e o dano sofrido pelo usuário, desde que o defeito não seja imputável aos revendedores intermediários nem a comportamento negligente do lesado. Vigora o mesmo regime para todos os integrantes da cadeia de distribuição, compreendendo quem quer que tenha feito publicidade ou aposto sua etiqueta na embalagem ou por qualquer meio beneficiado-se de divulgação que tenha despertado no consumidor uma justificável confiança. A condição perigosa deve existir no momento da entrega do produto à circulação e ser desconhecida pelo consumidor. A regra não se aplica aos vendedores não profissionais. $O$ ônus da indenização deve ser considerado um custo de produção, contra o qual o fabricante pode assegurar-se. ${ }^{12}$
Uma strict liability só é imposta por uma Corte norte-americana ao fabricante após um juízo preliminar sobre o dever de diligência, matéria exclusivamente de direito. Strict liability significa que quem causa um acidente é responsável pelos danos sofridos pela vítima, ainda que não fosse possível evitá-lo mediante a devida diligência. ${ }^{13} \mathrm{O}$ dever de diligência é exigível em alguns contratos, como compra e venda, locação, licenciamento de produtos etc. São levadas em conta razões de política de direito, como se a ré é uma empresa com finalidade de lucro, se ela pode compensar-se das perdas por meio de seguros ou aumentando o preço das mercadorias, qual é a frequiência de acidentes com seus produtos. Também é avaliado se era o produtor ou o usuário quem tinha melhores condições de prevenir o acidente. $O$ tribunal verifica aspectos relativos ao produto, aos seus possíveis defeitos, ao nexo de causalidade, ao dano e ao comportamento da vítima ou de terceiros. São pertinentes indagações do tipo: a apresentação do produto e seu uso normal induziam a uma expectativa de segurança? Qual era o uso normal do produto? O produto era defeituoso? Que espécie de defeito portava? Que risco o produto oferecia? O risco era superável mediante uso diligente? Existe produto concorrente mais seguro? O produto é socialmente útil, apesar de inseguro? Sua fabricação obedece às normas regulamentares? Ao ser lançado no mercado, o produto era considerado perigoso? As condições de insegurança apresentadas pelo produto foram essenciais para a produção do dano? Que danos resultaram: a pessoas, à coisa ou os danos foram econômicos? Houve culpa exclusiva ou concorrente da vítima ou de terceiros? Ainda ou${ }^{12}$ Conforme ALPA, G.. Una postilla sui modelli della "lettura" della circolazione di prodotti difettosi nell'esperienza
nord-americana. In ALPA, G.; BESSONE, M. (a cura di). Danno da Prodotti e responsabilitá dell'impresa. nord-americana. In ALPA, G.; BESSO
Milano: Giuffrè, 1980. p. 100-101.

${ }^{13}$ POSNER, Richard A. Economic analysis of law. $4^{\text {th }}$ ed. Boston: Litte, Brown and Company, 1992: 175 
tras questões são decididas no mesmo juízo, como a responsabilidade do comerciante, a extensão da proteção aos circunstantes e a inclusão ou não de riscos do desenvolvimento. ${ }^{14}$ Dessa forma, os tribunais assumem lugar importante na definição da política do direito nessa questão.

Razões dessa ordem apareceram em 1944, no caso Escola v. Coca-Cola Bottling Co. of Fresno, julgado pela Suprema Corte da Califórnia, que proclamou: "Ainda que a empresa não seja culpada, razões de ordem pública impõem que se impute a responsabilidade pela difusão de produtos defeituosos porque o empreendedor tem a oportunidade de reduzir os custos a que é exposta a vida e a integridade física dos consumidores em razão dos produtos defeituosos que circulam no mercado. (...) $O$ custo de uma lesão e das suas consequiências pode resultar excessivamente gravoso para o consumidor atingido, e em vão, porque o risco pode ser assegurado pelo produtor e distribuído entre o público como custo das operações econômicas empresariais." 15

2.1.2. Superação da Culpa e Extensão das Garantias Contratuais no Direito Continental Europeu

O desenvolvimento de um capítulo particular da responsabilidade civil para tratar dos produtos defeituosos é um mérito do direito norte-americano. A expressão "responsabilidade pelo fato dos produtos" foi traduzida da fórmula product liability. A partir dos anos 1960 uma série de acidentes graves ocorridos na Europa com produtos alimentares, cosméticos,

aparelhos domésticos, despertou os especialistas e os desviou dos preceitos tradicionais do contrato e do delito. ${ }^{16}$

A necessidade de uma proteção mais eqüitativa aos usuários provocou a inventiva de expedientes técnicos para sobrepujar as barreiras da responsabilidade civil comum.

2.1.2.1. Direito francês. $O$ direito francês, que ao contrário do direito inglês dispõe da noção de vício oculto, no art. 1.641, do Código Civil, utilizou-se dessa disciplina para impor ao fabricante obrigações de cunho contratual frente ao consumidor, diretamente. Segundo aquela disposição do Code Napoleón, o vendedor garante a coisa vendida contra defeitos ocultos sendo reputados tais os que tornam a coisa imprópria ao uso a que ela se destina, ou diminuam de tal modo a sua utilidade que o vendedor não a teria adquirido, ou teria pago menor preço, se tivesse conhecido os defeitos. $\mathrm{O}$ art 1.641 foi combinado com o art. 1.135, segundo o qual as convenções não obrigam apenas pelo que nelas se exprime, como também pelas consequiências derivadas da eqüidade, dos usos ou da lei, conforme a natureza da obrigação. Assim, ao colocar um produto no mercado, o fabricante tem uma obrigação principal, que é a entrega da mercadoria, e uma acessória, consistente na isenção de vícios. A jurisprudência francesa tem por definido que o vendedor profissional age de má fé ao vender um produto com vício, ou porque, em razão de sua profissão deveria conhecê-lo, ou porque, pelo mesmo motivo, não poderia ignorá-lo. Tal presunção assume caráter absoluto (iuris et de iure),

\footnotetext{
${ }^{14}$ Conforme VERTí, Dominick. Profili... Op. cit., passim.

${ }^{15}$ Apud ALPA, G. Una postilla.... Op. cit., pp p. 94.

${ }^{16}$ VINEY, G. La responsabilité du fait des produits en droit français. Revue International de Droit Comparé, Paris, v. 11, n. especial, p. 567-596
}

o que equivale a uma obrigação de garantia. ${ }^{17}$ A ação contratual, que é própria do adquirente, também pode ser fundada em culpa, quando há má conservação do produto ou falha nas informações de uso.

A importância do vice caché na jurisprudência francesa deve-se provavelmente à constatação objetiva do defeito da coisa, tendo havido decisões que por tal fundamento proveram a segurança do usuário. ${ }^{18}$

O fabricante responde diretamente frente aos consumidores, pela via extracontratual: a) quando for culpado, por fato próprio, pela existência de defeito do produto causador do dano; b) quando o dano decorre de um acidente causado por produto defeituoso (fato da coisa) que estava sob a sua guarda; c) quando o dano é causado pela conduta de um preposto.

A base da responsabilidade delitual do fabricante no direito francês repousa sobre os artigos 1.382 e 1.383, do Código Civil, que estabelecem a obrigação de reparar o dano a quem comete um fato culposo. ${ }^{19}$ Para transpor a prova da culpa, foi estabelecida uma presunção, reproduzindo-se o mecanismo da responsabilidade contratual por vício oculto, ou seja, o fabricante não pode ignorar o vício do seu próprio produto, presumindo-se a sua culpa. Para fundamentar a presunção, é lembrado o princípio spondet peritiam artis, segundo o qual deve responder pela sua arte aquele que se compromete a fazer alguma coisa com a habilidade própria a um profissional. A simples existência de um defeito seria então suficiente para res- ponsabilizar o fabricante, porque revelaria de plano duas espécies de culpa: desconhecer o defeito e colocar no mercado um produto defeituoso. O princípio citado, ao fim e ao cabo, é símile ao res ipsa loquitur. Com a presunção de culpa, a responsabilidade delitual do fabricante pode apoiar-se nos mencionados artigos 1.382 e 1.383 , cabendo à vítima provar apenas a existência do vício. A presunção de culpa é absoluta, mas é franqueada ao fabricante a prova de causa estranha para livrar-se da reparação.

A jurisprudência nessa matéria não é expressiva, exceto por dois acórdãos. O primeiro impõe ao fabricante o dever de se manter atualizado no seu ramo de atividade. Nesse caso, cuidava-se de lesões físicas causadas por uma loção capilar, sendo demandados pela indenização o fabricante e o cabeleireiro que fez a aplicação. O tribunal fundamentou a condenação do fabricante numa publicação médica que tachara de perigoso um produto químico componente da fórmula da loção, o que o fabricante, “em razão de sua atividade, não podia e não devia ignorar". Novamente trata-se de aplicação do princípio spondet peritiam artis, ensejando a aplicação da máxima de que "o fabricante não pode nem deve ignorar os vícios da coisa". ${ }^{20} \mathrm{O}$ segundo acórdão cassa uma apelação porque o proprietário de um automóvel que demandava indenização contra o fabricante não provou nenhuma culpa contra o réu. Ocorrera um acidente por defeito do sistema de freios. O fundamento da cassação foi que esse defeito constituiria em si mesmo uma base culposa para a condenação. Portanto, a culpa

${ }^{17}$ Nesse sentido, GRUBER-MAGITOT, LAAction... Op. cit., pp. 36-37. Para CRÉPEAU, Paul-André (L'Intensité de l'Obligation Juridique ou des Obligations de Diligence, de Résultat et de Garantie.Québec: Yvon de 1908: 12 insirando-se em Mazeaud e Tunc), a origacão de gantia tem maior intensidade do que a de

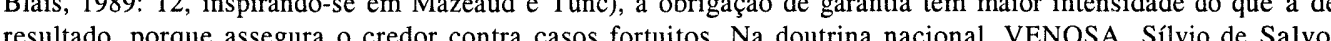
. Direito Civil: Teoria Geral das ( ${ }^{18}$ VINEY, G. La responsabilité...,Op. cit. P. 570

${ }^{19}$ Art. 1.382: quem quer que, por culpa sua, cause a outrem um prejuízo, fica obrigado a repará-lo. Art. 1.383: cada um é responsável pelos prejuizos que causa, não somente por culpa, mas também por negligência ou imprudência. ${ }^{20}$ GRUBER-MAGITOT, L'Action...”. Op. cit., p. 96. 
estaria na simples incorporação ao automóvel de peças defeituosas, o que é quase dizer que o fabricante deveria conhecer o vício da peça. Tal afirmação, que não é feita, seria o reconhecimento explícito da presunção de culpa, que resta, portanto, velada. ${ }^{21}$

No segundo fundamento, o fabricante responde pelo fato da coisa que estava sob a sua guarda. A responsabilidade por fato da coisa, no direito francês, que tem base no art. 1.384, do Código Civil, é fundada sobre a guarda e não depende de culpa, oferecendo grande vantagem à vítima, a quem bastará demonstrar que o dano adveio da coisa em custódia. Tratase de uma "presunção de responsabilidade", ou "responsabilidade de pleno direito", não de uma responsabilidade por culpa presumida. ${ }^{22}$ No entanto, como raramente a guarda de um produto defeituoso permanece com o fabricante, a doutrina inovou a teoria da guarda, desmembrando a clássica unidade de uso, direção e controle em duas concepções distintas e independentes: guarda da estrutura e guarda do comportamento (uso). O proprietário de um objeto é guardião do seu uso (guardião de comportamento) e só responderá pelo dano eventualmente causado se agir com culpa própria Sendo o vício oculto um defeito estrutural da coisa, o fabricante permanece como guardião da estrutura, respondendo pelos danos daí resultantes, a menos que o defeito tivesse sido descoberto ou que à coisa se tivesse imprimido

${ }^{21} I d .$, ib., pp. 96-97.

${ }^{22}$ Conforme GRUBER-MAGITOT, citando literalmente duas decisões da Corte de Cassação. L'Action..., Op. cit., p. 99; uma responsabilidade particularmente pesada, porque prescinde da prova culpa e mesmo do defeito ${ }^{23}$ Conforme GRUBER-MAGITOT, S. L'Action.... Op. cit., pp. 100-101.

${ }^{24}$ Apud CALVÃO DA SILVA, J. da. Responsabilidade civil do produtor. Coimbra: Almedina, 1990. p. 418.Em outra decisão, de 16/1/91, a Corte de Cassação decretou a responsabilidade do fabricante de um poste, como guarda da estrutura, pelo incêndio e queda sobre um prédio, causando também o incêndio do mesmo (captada na Internet). ${ }^{25}$ MALINVAUD, Philippe. I vizi redibitore e il loro ruolo nella vita moderna. In ALPAe BESSONE (a cura di). Danno da Prodotti. Op. cit. pp. 261-262.

${ }^{26}$ CALVÃO DA SILVA, J.da. Op. cit., p. 419. O autor menciona em nota a adesão de Starck e de Mazeaud/Tunc à tese da solidariedade dos dois guardiões.

${ }^{27}$ Pelo sim, os irmãos MAZEAUD; pelo não, STARK, apud GRUBER-MAGITOT, S. Op. cit. p. 104.

Revista da Faculdade de Direito da UFRGS, v. 20, Outubro/2001 feituosos e o favorecimento às empresas. $\mathrm{O}$ Código Civil, por exemplo, responsabiliza o proprietário, o usufrutuário, o aderente com pacto de reserva de domínio e o condutor por danos causados a terceiros por vícios de construção do veículo (art. 2.054). ${ }^{28}$ A figura das relações contratuais de fato não teve muito êxito como fundamento da responsabilidade do fabricante, uma vez que não existe contato pré-negocial com o consumidor e o argumento da mediatização da publicidade era inservível quando o produto não era anunciado ou já tivesse cessado a campanha publicitária. Foi lembrado o art. 1.337, do CC, que obriga as partes, durante as tratativas e na formação do contrato, a comportar-se segundo a boa-fé - considerado inaplicável, contudo, porque se volta para relações pré-contratuais. Nem mesmo os deveres de informação e de fabricação diligente, deduzidos da boa-fé, fizeram carreira, porque pertencem à fase de execução do contrato, não à da tratativa. A tutela do consumidor foi considerada mais apropriada com base no art. 1.494, segunda parte, do CC: "o vendedor deve ainda ressarcir ao comprador os danos derivados dos vícios da coisa". A ausência de qualquer referência à culpa na dicção legal deu lugar à sustentação de uma responsabilidade objetiva, posição contestada pelos partidários de uma interpretação sistemática. Segundo a doutrina dominante, os danos compreendiam as lesões pessoais do comprador ou de terceiro e o prejuízo da coisa. O ressarcimento devia ser perseguido junto ao vendedor (comerciante), o qual buscaria regresso com o fabricante. Ficava em aberto se o dano ao consumidor era indireto, uma vez que o art. 1.323 só assegura indeniza-

ção de dano direto. ${ }^{29}$ Outra construção doutrinária e jurisprudencial serviu-se do art. 2.043 , $\mathrm{CC}$, segundo o qual, "qualquer fato doloso ou culposo que causa a outrem um dano injusto obriga a quem cometeu o fato indenizar o dano". Sob o texto foi incluída a proteção inclusive ao bystander. Mesmo o dano imprevisível deve ser indenizado, desde que faça parte do risco típico da empresa. Esse regime, desamparado de previsão legislativa, onerou a empresa para evitar que o dano fosse suportado pelo consumidor. A culpa não é encarada como fundamento único da responsabilidade civil, aludindo-se também a uma "culpa objetiva", a presunção de culpa e o risco. ${ }^{30}$

Entendem alguns que a empresa deve responder pelo fato do produto com base na culpa somente se o dano é causado por defeito de projeto, tornando-se objetiva a responsabilidade se o defeito é de construção, controle ou informação. ${ }^{31}$ Outros preferem aplicar o critério da culpa para os danos evitáveis, como estímulo à empresa no aperfeiçoamento dos produtos, deixando o critério objetivo para os danos inevitáveis. ${ }^{32}$

A jurisprudência italiana seguiu duas orientações: a) o empreendedor é obrigado desenvolver a sua atividade adequando a estrutura da empresa ao desenvolvimento da técnica, de modo a prevenir qualquer dano a terceiro, ainda que as medidas que deva adotar não sejam próprias do seu ramo industrial; b) o empreendedor deve tomar as medidas exigíveis segundo a boa-fé. Nessas orientações, a boafé assume uma significação ambígua. De um lado, é brandida pelo consumidor para funda-

${ }^{28}$ Profili della responsabilitá del produttore nell'esperienza italiana". In ALPA e BESSONE (a cura di). Danno da Prodotti. Op. cit, p. 11-38 [18]

${ }^{29}$ BESSONE, Profili .... Op. cit., p. 32-36.

${ }^{30}$ Idem, ib., pp. 21-24.

${ }^{31}$ Assim CARNEVALI, apud BESSONE, Profilli... Op. cit., p. 26

${ }^{32}$ Conforme GHIDINI, apud BESSONE, Op. loc. cit.

Revista da Faculdade de Direito da UFRGS, v. 20, Outubro/2001 
mentar um regime de responsabilidade mais rigoroso para o fabricante. O consumidor adquire um produto animado pela expectativa da sua utilidade, imaginando a isenção de qualque defeito. A boa-fé estabelece uma conexão direta e imediata entre a confiança despertada pelo fabricante e a crença do consumidor na plausibilidade da promessa - uma boa-fé com carga subjetiva. Com a manifestação do defeito, o fabricante também apela para a boa-fé como argumento de inexigibilidade de outra conduta, pretendendo um abrandamento da sua responsabilidade, em vista da impossibilidade concreta de ter evitado o dano. ${ }^{33}$ Este último argumento só é aceitável na inexistência de regra de responsabilidade objetiva.

2.1.2.3. Direito alemão. Na Alemanha, a responsabilidade do fabricante por produtos defeituosos, tradicionalmente, podia ter natureza contratual ou extracontratual, ambas com base na culpa. A responsabilidade contratual tinha por fundamento uma lesão positiva do contrato. No entanto, se o fabricante fornecesse uma garantia do produto, não era necessária a prova da culpa. Em muitos casos, a jurisprudência considerava certas garantias implícitas. ${ }^{34}$ Mais adiante, sob influência da Comunidade Européia, prevaleceu a fundamentação extracontratual. A culpa, no entanto, mantinha sua posição. A doutrina germânica, quase à unanimidade, considerava temerária uma responsabilidade com base no risco da empresa, posição que em grande medida se justificava pelo fato de que, embora fosse dominante a aceitação de uma responsabilidade objetiva mesmo sem previsão legislativa, a inversão do ônus da prova pelos tribunais já tinha proporcionado uma considerável extensão do regime de responsabilidade. ${ }^{35}$ Assim: o ônus da prova contra o patrão era agravado, exigindo a demonstração de cuidado na escolha e vigilância do empregado; foi considerado presumido o defeito da organização (com base no § 831, BGB) como causa do defeito do produto, pois uma suficiente articulação de meios de segurança e controles certamente o teria evitado. Por outro lado, foram criadas facilidades para o consumidor. A prova dos defeitos de construção era considerada suficiente mediante meros indícios e para o nexo causal bastava uma aparência de prova. A pretensão indenizatória de natureza contratual protegia, além do adquirente, os seus familiares, hóspedes e dependentes. A via extracontratual abriu-se a qualquer lesado, inclusive os bystanders, prevalecendo mesmo em acidentes com máquinas industriais. ${ }^{36}$

A decisão que marcou a predominância do fundamento extracontratual na responsabilidade civil do fabricante foi tomada pelo Bundesgerichtshof em 1968, que assentou a predominância do $\S 823$, alínea 1 , do BGB, com inversão do ônus da prova da culpa. ${ }^{*} \mathrm{O}$ fundamento da responsabilidade do fabricante é a violação de uma obrigação de prevenção de perigo. Coerentemente com essa visão, a juris-

${ }^{33}$ BESSONE, Mario.Profili della responsabilità del produttore nell'esperienza italiana. In ALPA e BESSONE Danno da Prodotti...”. Op. cit., p. 25

${ }^{34}$ MARSCHALL VON BIEBERSTEIN, W. La responsabilità da prodotti nel diritto tedesco. In ALPA e BESSONE (a cura di). Danno da Prodotti..., Op. cit., pp. 165-185, passim.

${ }^{35}$ ARATO, Marco. La dottrina tedesca e la direttiva proggetuale della CEE. In ALPA e BESSONE (a cura di). Danno da Prodotti..”. Op. cit., p. 185-189.

${ }^{36}$ MARSCHAL VON BIERBENSTEIN, La responsabilità... Op. cit., p. 174-182.

* "\$ 82.3. Dever de ressarcimento de danos. 1. Aquele que dolosa ou culposamente lesa injustamente a vida, o corpo a sá́de a liberdade, a propriedade ou qualquer direito de outra pessoa, fica obrigado frente a ela a ressarcir o dano que causou".

Revista da Faculdade de Direito da UFRGS, v. 20, Outubro/2001 prudência alemã, apesar de rejeitar categoricamente a responsabilidade por risco do desenvolvimento - exceto no setor de medicamentos -, impõe ao fabricante um dever de acompanhar o produto mesmo depois de sua comercialização, advertindo o público sobre a descoberta ulterior de um risco desconhecido. Todavia, a lei que adaptou a diretiva não positivou a regra pretoriana, abrindo flanco à crítica de favorecimento à indústria. ${ }^{37}$

2.2. Fontes Alternativas da Responsabilidade Civil e o Advento da Diretiva Européia

O terreno tradicional da responsabilidade civil foi modificando-se no compasso da crescente importância assumida pelos acidentes com produtos defeituosos. Verificou-se uma convergência dos regimes contratual e delitual, sendo alguns de seus sintomas principais: a ineficácia das cláusulas limitativas de responsabilidade, que eram aceitáveis nos contratos em razão da autonomia da vontade; a assimilação da culpa profissional à culpa grave, implicando considerar o defeito um ato intencional em razão da paridade da culpa grave com o dolo; a assimilação do vendedor profissional a vendedor de má fé em face de um vício oculto; e principalmente o conteúdo das obrigações em matéria de segurança, que resguarda contra os usos e riscos dos produtos tanto o adquirente quanto terceiros. ${ }^{38}$

A confluência dos regimes clássicos do contrato e do delito leva à formulação de uma terceira fonte de responsabilidade civil, que pressupõe uma interação social que não se concretiza num contrato nem ingresse no terreno ilícito do delito.
A pavimentação dessa terceira via da responsabilidade civil fundamenta-se em deveres de proteção da integridade alheia, impondo um modo de agir que evite prejuízos ao parceiro relacional. A idéia motriz é uma solidariedade que deve permear o contato social, toda vez que ele se intensifica, indo além da vida de relação anônima ou eventual. Os deveres de proteção não se vinculam nem ao contrato nem ao delito. Eles constituem "a juridificação de uma moral da interação". ${ }^{39}$ A responsabilidade civil adviria da violação de um comportamento singular, exigível no quadro de uma relação concreta. A sua justificação é a legitimidade do interesse de conservação dos próprios bens, peculiar a qualquer um

Para a fundamentação jurídica dessa responsabilidade concorrem várias doutrinas, que têm em comum a justificativa de uma fonte de responsabilidade civil autônoma em relação àquelas clássicas do contrato e do ato ilícito.

\subsubsection{Em busca de uma Terceira Via da Res-} ponsabilidade Civil

As mais expressivas teorias alternativas ao contrato e ao delito como fontes de responsabilidade civil são a do contato social e a da proteção à confiança, que ao fim e ao cabo apresentam aspectos de complementaridade. Ambas constituem idéias que fundamentam deveres sem origem em vínculos jurídicos previamente estabelecidos, como os contratos, ou na contrariedade a condutas estipuladas em lei, como os atos ilícitos. Esses deveres surgem dos usos do tráfico e se revelam no campo sociológico, entrando no mundo jurídico por motivo de sua repercussão econômica.
${ }^{37}$ SCHWENZER, Ingeborg. L'adaptation de la directive communautaire du 25 juillet 1985 sur la responsabilité du fait des produits défectueux en Allemagne Fedérale. Revue Internationale de Droit Comparé. Paris: n. 1. 43. ano, p. 57-74, jan.mars 1991).

${ }^{38}$ Nesse sentido, comentando sobre o direito francês, VINEY G., La responsabilité.... Op. cit., P. 580-584.

${ }^{39}$ TEUBNER, apud FRADA, Manuel A. Carneiro da. Contrato e Deveres de Proteção. Coimbra, 1994: 266. 
A contribuição dessas teorias foi importante para superar a rigidez dos esquemas tradicionais do direito, comprometidos com os conceitos hegemônicos de contrato e delito. Mas não lograram consolidar uma posição indisputável. De um lado, ressuscitam as idéias romanas de quase-contrato e quase-delito. De outro lado, comportamentos concludentes podem substituir declarações de vontade na formação de vínculos contratuais, ficando dentro da teoria do negócio jurídico as situações que as teorias alternativas se propõem a explicar. Por fim, há que se evitar confusão com a boa-fé.

\subsubsection{Contato social, confiança e deveres de} proteção. O que se chama de contato social é o momento fático em que os indivíduos passam de uma convivência impessoal, diluída no anonimato, para uma situação particular, que adquire significado jurídico. Na convivência anônima a integridade de cada um está protegida pela regra nenimen leadere. No contato social passa a existir um relacionamento particular, em que alguém fica exposto à atuação ou influência de outrem, sem que necessariamente o passo seguinte seja a celebração de um negócio jurídico ou que ocorra um ato ilícito. Essa proximidade exige uma conduta especialmente cuidadosa por parte de quem possa eventualmente prejudicar o patrimônio jurídico alheio.Há un incremento de perigo por um lado e um acréscimo de responsabilidade pelo outro. O eventua dano sofrido por uma das partes durante esse contato social é indenizável, e o fundamento jurídico da obrigação de fazê-lo é a confiança.

"A confiança exprime a situação em que uma pessoa adere, em termos de atividade ou de crença, a certas representações, passadas presentes ou futuras, que tenha por efetivas". 40 Como está presente de modo geral no relacionamento humano (o pedestre atropelado confiava que o motorista respeitasse as regras de trânsito), a confiança deve ser o elemento determinante da conduta do lesado para poder fundamentar uma responsabilidade autônoma. Por conseguinte, somente uma concepção psicológica do princípio da confiança o legitima, pois uma conceituação normativa o confundiria com o dever geral de não infringir danos (regra neminen leadere), fundamento do ato ilícito. Sempre será necessário avaliar a subjetividade do lesado para saber se ele podia confi$\mathrm{ar}^{41}$ Portanto, fórmulas como "confiança digna de proteção jurídica" e "legítimas expectativas" não valem por si mesmas, necessitando invariavelmente de preenchimento fático. A confiança serve muitas vezes para limitar, outras para concretizar o contato social. ${ }^{42}$

A confiança "constitui, por excelência, uma ponte entre as boas-fés objetiva e subjetiva", como expressou Menezes COR$\mathrm{DEIRO}^{43}$, salientando que "a aproximação entre confiança e boa fé constitui um passo da Ciência Jurídica que não mais se pode irrealismo metodológico de compor litígios

${ }^{40}$ MENEZES CORDEIRO, Antonio Manuel da Rocha e. Da Boa Fé no Direito Civil. Coimbra: Almedina, 1984, II: 1234

${ }^{41}$ V. CARNEIRO DA FRADA, M. A., Contrato e Deveres de Proteção. Op. cit., p.252-253.

${ }^{42}$ Assim Dölle, Esser-Schmitdt, Thiele e Heinrich Stoll, apud FRADA. Op. cit., p. 249.

${ }^{43}$ Da boa fé.... Op. cit., v. II, p. 1238.

Revista da Faculdade de Direito da UFRGS, v. 20, Outubro/2001

com metadiscursos. ${ }^{44} \mathrm{~A}$ confiança tem raízes éticas que lhe conferem um conteúdo material a ser comunicado à boa fé. Ela é um fator de redução da complexidade social, na medida em que leva o fiduciante a descartar muitas das inúmeras eventualidades capazes de desencadear comportamentos humanos. O direito produz o mesmo efeito de redutor da complexidade, sendo uma fonte primordial de confiança. Numa sociedade dominada pela impessoalidade, o teor de confiança existente num contrato resulta mais da inserção do negócio em canais jurídicos pré-determinados do que de expectativas recíprocas de comportamento. A confiança gerada pelo direito decorre da previsibilidade proporcionada pela ordem jurídica. ${ }^{45}$ Enquanto as garantias legais infundem confiança ao cidadão, a falta de efetividade da lei constitui quebra da promessa.

A confiança se expressa no ordenamento jurídico por meio de disposições legais específicas ou de proteções genéricas albergadas em conceitos indeterminados. A primeira espécie reflete situações de boa-fé subjetiva e a segunda, de boa-fé objetiva. São exemplos de disposições legais específicas, inspiradoras de proteção em razão de confiança proveniente de boa-fé subjetiva: os efeitos, perante contraentes de boa-fé, do mandato aparente (art. 1.321, CC), mesmo que a lei não refira, de modo expresso, a boa-fé (a validade dos atos praticados pelo herdeiro excluído - art. 1.600, CC) ${ }^{46}$ As proteções de caráter genérico são

${ }^{44}$ Idem, ib., v. II, p. 1241

${ }^{45}$ Conforme CORDEIRO. Op. cit., v. II, p. 1243.

${ }^{46}$ Muitas disposições legais semelhantes são creditadas na literatura jurídica nacional à teoria da aparência, tal como o pagamento feito de boa-fé ao credor aparente (art. 935, CC) - e.g., RÁO, Vicente. Ato Jurídico. $3^{\text {a }}$ ed. São Paulo: Revista dos Tribunais, 1994. p. 205. Em casos como o exemplificado a confiança não integra necessariamente a aparência, como fica mais evidente na proteção ao possuidor de boa-fé (art. 510, CC), em que não existe um fiduciante. A eventual assimetria entre confiança e aparência foi gizada por Menezes CORDEIRO (Da Boa Fé... Op. cit. v. II, p. 1234). Contudo, para CANARIS, a aparência é tipicamente uma causa de responsabilidade pela confiança, do mesmo modo que alguns imperativos ético-jurídicos, declarações e intromissões lesivas. Apud FRADA, Manuel A. Carneiro da. Contrato e Deveres de Proteção, cit., 250

${ }^{47}$ V. CORDEIRO (Da Boa Fé... Op. cit. v. II, p. 1244).

${ }^{48}$ Idem, ib., v. II, p. 1247-1248.

${ }^{49}$ Apud João Calvão da SILVA, Responsabilidade civil do produtor, cit., p. 342, nota 5.

(x).

Revista da Faculdade de Direito da UFRGS, v. 20, Outubro/2001 relativas à boa-fé objetiva, exigindo uma conduta capaz de legitimar uma posição jurídica, tal na suppressio e na surrectio. ${ }^{47}$ Segundo MENEZES CORDEIRO, fora das disposições egais específicas, a confiança deve ser motivo de proteção jurídica quando houver atuação

A factualidade da violação dos deveres e proteção não pode ser confundida com o u regime. A violação ocorre em situações de zam em condutas exigíveis ou proibidas, mas a inexistência de um acordo prévio afasta o regicomo a imputação por fato de terceiro. que os deveres de proteção, que antecedem e sobrevivem ao contrato, formam uma relação vontade. A relac̃ão de confiança, por conseguinte, pode estabelecer-se entre fabricante e ao passo que a relação de prestação somente forma entre os elos da cadeia produtiva. ${ }^{49}$

A necessidade de proteção da integridade levou à combinação de regras de natureza delitual com o regime jurídico próprio dos con位os. Não fosse assim, seria imprópria a

Revista da Faculdade de Direiro da UFRGS, w 20 . Outubro/2001 
tratos, uma situação híbrida, que ensejou as denominações contort ${ }^{50}$ e Sonderdelikte. ${ }^{51} \mathrm{Po}$ rém, diferentemente do contrato, não há acordo negocial como base da responsabilidade; e, dis tintamente do delito, o ponto de partida não é violação pura e simples de uma regra de abstenção de conduta por parte do lesante, mas a aquiescência do lesado a uma possibilidade de interferência do lesante que o lesado confia que não ocorrerá. Na relação obrigacional emergente, situa-se no pólo credor (de credere, confiar) aquele que confia, cuja conduta fiduciante portadora de eficácia jurígena; no pólo devedor, o fiduciário, cujos deveres de proteção são a contrapartida de sua autonomia negocial, no exercício da qual opta por tornar-se guardião de bens alheios no transcurso relacional que consulta o seu interesse..$^{52}$

Em conclusão: existem deveres no contato social, fora do contrato e aquém do delito. O princípio que lhes infunde juridicidade é a confiança. A violação de tais deveres, dirigi dos à proteção alheia, implica a obrigação de reparar os danos. O critério de aferição dessa responsabilidade é a boa-fé. Vista objetivamente, a boa-fé é uma exigência de conduta ética leal, que se impõe ao lesante. De outro lado, ela será a medida de aferição do comportamento do lesado, de acordo com a sua representação subjetiva da realidade, autorizada pelos fatos que lhe era possível conhecer e por sua verossimilhança.

2.2.1.2. Boa-fé e incremento das pretensões contratuais. A difusão do princípio da boa-fé expandiu o conteúdo das obrigações contratuais, internalizando nos acordos de vontade situações que antes só eram cobertas no regime extracontratual. Ficou assim diminuída a importância da barreira representada pela regra non cumul, que não permitia a veiculação de pretensão delitual ante um incumprimento contratual, ainda que a via compulsória - no caso, a do contrato - trouxesse inconvenientes, tais como prazos prescricionais mais reduzidos e exclusão de alguns danos da possibilidade de reparação. A regra non cumul foi adotada, por exemplo, na França, e também no Brasil, em vista da disciplina separada que o Código Civil dedica às obrigações contratuais e às provenientes de delito. Já outros sistemas, como o germânico, admitiram uma facultas alternativa, permitindo que o lesado escolhesse a via de sua conveniência. ${ }^{53}$ No direito inglês, depois que o princípio formulado no caso Donoghue v. Stevenson (1932), de que os fabricantes respondem por danos causados por seus produtos aos consumidores se generalizou pela sua repetição numa série de outros julgados, a via da ação delitual foi aberta também aos contratantes. $O$ fatalismo da alternativa, contrato ou delito, foi colocado em xeque com o debate sobre os atos existenciais, que ganhou importância com a estandardização do tráfego. Nos atos existenciais, a vontade não é condição de eficácia. Portanto, o regime a eles aplicá-

${ }^{50}$ Contração de contract com tort (delito civil no common law), termo cunhado por GILMORE. Apud FRADA. Contrato e Deveres de Proteção, cit., p. 263.

${ }^{51}$ Delito especial, assim definido por GERT BRÜGGEMEIER. Apud FRADA. Op. cit., p. 264. FRADA acaba aderindo ao quase-contrato como figura apta a representar essa terceira via de responsabilidade, diferente do contrato e do delito (Op. cit., p. 272).

${ }^{52}$ No mesmo sentido, FRADA. Op. cit., p. 272.

${ }^{53}$ Nesse sentido, WEITNAUER, H. Remarques sur l'évolution de la responsabilité civile délictuelle en droit allemand. Revue International de Droit Comparé, Paris: n. 19, 1967, p. 810.

Revista da Faculdade de Direito da UFRGS, v. 20, Outubro/2001 vel não pode ser o contratual, porque, à míngua de manifestações válidas, o juiz não teria substrato para decidir sobre o conteúdo das obrigações. De delito, evidentemente, também não se trata. A solução de melhor alvitre é considerar os atos existenciais, atos materiais. No plano processual, a pretensão é veiculada no pedido e fundamenta-se nos fatos a que o mesmo se reporta, encontrando plena ressonância no art. 282, III, do Código de Processo Civil, que consagra o princípio da substanciação da causa de pedir. ${ }^{54}$

2.1.3. Refluxo às fontes tradicionais. Não colhem unanimidade, porém, as teorias unitárias de responsabilidade civil. Parte ponderáve da doutrina adapta a teoria clássica das fontes ao tráfico de massa. A formação dos vínculos contratuais bipolariza-se em declarações de vontade e comportamentos concludentes. Nos contratos de massa, conjugam-se uma oferta uma conduta. A confiança, nesse caso, não é o pressuposto de fato que origina uma responsabilidade in contrahendo, mas o nexo causal da obrigação de indenizar o interesse negativo. ${ }^{55}$ Dispõe nesse sentido o § 307, do Código Civil alemão, impondo àquele que conclui um contrato conhecendo com exclusividade ou deven- do conhecer a impossibilidade da prestação, a obrigação de indenizar a parte lesada que confiou na validade do negócio.

2.2.2. A Consolidação da Responsabilidade

A evolução da matéria da responsabilidade do fabricante no direito europeu, que por caminhos diversos chegou a idênticas soluções nos sistemas do common law e do civil law, convergiu para o concurso dos regimes contratual e extracontratual, com o fim de assegurar maior proteção às vítimas. Foi essa a solução consagrada na Diretiva 85/374, da Comunidade Econômica Européia, que promoveu uma unificação das responsabilidades contratual e extracontratual, tornando sem interesse a vinculação do dano a um regime ou outro. ${ }^{56}$

A Diretiva em referência harmonizou o direito europeu aplicável a produtos defeituosos e representou uma culminância legislativa, desdobrada para o direito interno dos países membros, depois que os tribunais, sensíveis à necessidade de propiciar um patamar de proteção efetiva aos consumidores, lograram atrair para o mesmo esforço o legislador. ${ }^{57}$ Civil do Fabricante na Diretiva 85/374/CEE

${ }^{54}$ Sobre os temas da regra non cumul e da facultas alternativa, bem como sobre atos existenciais, foi importante a contribuição do Prof. Clóvis do Couto e SILVA, em várias passagens de sua obra, tais como: Principes fondamentauxde la responsabilité civile em droit brésilien et comparé. Trabalho inédito, no acervo da Faculdade de Direito da UFRGS; Para uma história dos conceitos no direito civil e no direito processual civil. Boletim da Faculdade de Direito. Coimbra: v. LVIII, 1982, p. 311-372.

${ }^{55}$ FLUME, W. El negocio jurídico. Madrid: Fundación Cultural del Notariado, 1998. p. 166, t. 2.

${ }^{56}$ Assim CALVÃO DA SILVA J., segundo quem, "a querer catalogar-se na antiga dicotomia a responsabilidade (...), ela não pode deixar de ser havida como extracontratual, já que é independente de qualquer relação contratual entre o produtor e o lesado", acrescentando que "a summa divisio é antiga e continua a existir, concorde-se ou não"
(Responsabilidade civil... Op. cit., pp. 478-9). Sendo assim, a proclamada unificação de regimes é especial, não derruindo os alicerces da ancestral construção aquiliana. Também não tem trânsito a doutrina da confiança, de Canaris, por ele mesmo denominada de terceira pista ("dritte Spur") da responsabilidade civil. CALVÃO DA SILVA a considera artificial, por decompor uma relação obrigacional em duas (relação de confiança e relação de prestação). $\mathrm{O}$ autor português cita decisão do Supremo Tribunal alemão, que rejeita a teoria de Canaris, por suprimir os limites existentes entre os domínios contratual e extracontratual (Op. cit., p. 343). Parece-nos que a doutrina de Canaris ou qualquer outra "terceira pista", com a denominação que se lhe possa dar (contato social, conduta social típica, atos existenciais, relações contratuais fáticas etc.) tem o mérito de revelar uma área de responsabilidade intermediária, extracontrato e extradelito, autônoma em relação a ambos. A delimitação desse território não exclui a unificação dos dois regimes, porque em ambos vigoram regras híbridas. A questão a discutir é se é só um ou se são dois territórios.

s7 VINEY, G. La responsabilité.... op. cit, p. 569.

Revista da Faculdade de Direito da UFRGS, v. 20, Outubro/2001 

tado membro ou a transposição incorreta da gura na aplicação dos Regulamentos. Por con-
2.2.. A eficácia das Diretivas na Comunidade Européia. Conforme o Tratado de Roma, diretiva, decisão do Conselho da Europa, "vincula o Estado membro destinatário quanto ao resultado a alcançar, deixando, no entanto, às instâncias nacionais a competência quanto à forma e aos meios" (art. 189, $3^{\text {a }}$ parte).

A harmonização como efeito de uma diretiva pode ocorrer pelo implemento legislativo no plano interno de cada Estado membro, adaptando ao seu ordenamento jurídico o regime proposto, ou por aplicação direta da diretiva.

A Diretiva 85/374 concedeu aos Estados membros o prazo de três anos para a implementação dos atos legais visando a sua transposição para o direito interno. Alguns países excederam o prazo. ${ }^{58} \mathrm{~A}$ omissão de um Esdiretiva pode ser suprida pelo chamado efeito direto, consagrado pelo tribunal comunitário no caso Becker-Finanzamt Münster-Innenstad de 1982. Contudo, o efeito direto, no caso de uma diretiva, opera apenas no sentido vertical, impondo-se aos Estados membros, mas não ao particulares. O efeito direto integral só se confiseguinte, um particular pode invocar contra um Estado membro a aplicação de uma disposição direta $\mathrm{e}$ incondicional da diretiva, mas não obterá o mesmo efeito contra outro particular. ${ }^{59} \mathrm{~A}$

fundamentação do efeito direto é a doutrina do stoppel, corolário da boa-fé, segundo a qual, no caso em questão, um Estado não poderia negar direitos decorrentes da aplicação da diretiva, opondo o seu próprio incumprimento da obrigação de internalizá-la. ${ }^{60}$

Tendo em conta o efeito vinculativo das diretivas, o Tribunal de Justiça das Comunidades Européias decidiu, no caso Von Colson e Kamann, julgado em 10 de abril de 1984 , que as jurisdições nacionais devem interpretar o direito interno à luz do texto e da finalidade da diretiva. ${ }^{61}$

Outro mecanismo de harmonização do direito europeu é o reenvio prejudicial. $\mathrm{O}$ art. 177 do Tratado de Roma prevê essa figura, que faculta aos órgãos jurisdicionais dos Estados membros requerer um pronunciamento prévio do Tribunal de Justiça comunitário quando a decisão da causa implicar uma interpretação do Tratado ou de atos emanados das instituições comunitárias, tais como as diretivas. Através do reenvio prejudicial é assegurada uniformidade de interpretação do direito comunitário.

2.2.2.2. Bases do regime de responsabilidade na Diretiva 85/374/CEE. A Diretiva 85/374 dispõe que o produtor será responsável pelos danos causados por defeitos dos seus produtos, ${ }^{62}$ podendo ser responsabilizado também o im-

${ }^{58}$ Cumpriram o prazo Grécia, Grã-Bretanha e Itália (Decreto 224, de 24/5/88). Atrasaram-se Portugal (Decreto 383/89, de 6 de novembro) Alemanha (a já mencionada Lei de Responsabilidade pelo Fato de Produtos Defeituosos, Produkthaftungsgesetz, de 15/12/89) e Espanha (Lei 22/1994, de 6 julho).

${ }^{59}$ Apud Calvão da SILVA, "Responsabilidade...”, Op. cit. p. 460.

${ }^{60}$ Tal a decisão do tribunal comunitário na "Sentença Ratti", apud GARAU, Guillermo Alcover, La

${ }^{61}$ Apud Calvão da SILVA. Responsabilidade... Op. cit. p. 454.

62 "Art. $1^{\circ}$. O produtor é responsável pelo dano causado por um defeito do seu produto". Note-se a extensão do conceito de produtor, que aparece no art. $3^{\circ}, 1$ : "O termo 'produtor' designa o fabricante de um produto acabado, o produtor de uma matéria-prima ou o fabricante de uma parte componente, e qualquer pessoa que se apresente como produtor pela aposição sobre o produto do seu nome, marca ou qualquer outro sinal distintivo".

Revista da Faculdade de Direito da UFRGS, v. 20, Outubro/2001 Responsabilidad Civil del Fabricante. Madrid: Civitas, 1990. p. 45. portador ${ }^{63}$ Não sendo o produtor identificado, poderá responder pela indenização qualquer fornecedor, livrando-se, no entanto, se indicar ao lesado a identidade do produtor "num prazo razoável". ${ }^{64}$

A Diretiva, conforme consiga a exposição de motivos, aplica-se somente a bens móveis produzidos industrialmente, ${ }^{65}$ excluídos produtos agrícolas e da caça, a menos que tenham passado por processo industrial de transformação.

Tem o prejudicado o ônus de provar o

Nada é aludido com relação ao fator de imputação, entendendo-se prescindível a culpa, mesmo porque, segundo a exposição de motivos, "unicamente o critério da responsabilidade objetiva permite resolver o problema, tão próprio de uma época de crescente tecnicismo como a nossa, da justa repartição dos riscos inerentes à produção técnica moderna". Também são incluídos os importadores (art. $3^{\circ}, 2$ ) Havendo duas ou mais pessoas causadoras do mesmo dano, haverá solidariedade entre elas (art. $4^{\circ}$ ).

Não há preocupação dogmática em enquadrar a responsabilidade dos sujeitos passivos no campo contratual ou extracontratual. Ao dano, o defeito e o nexo causal. ${ }^{66}$ contrário, iguala-os, ao tornar responsável qualquer distribuidor colocado na cadeia de fornecimento nos casos em que o produtor, compreendido nos termos já explicitados, não puder ser identificado (art. $3^{\circ}, 3$ ). Também institui a solidariedade pela reparação entre todos os que concorreram para o dano $\left(\operatorname{art.~} 5^{\circ}\right)$.

\section{Responsabilidade Civil do Fabricante no Quadro do Mercosul}

A eviolução das idéias nos sistemas common law e continental europeu, bem como a posterior harmonização comunitária do regime de responsabilidade civil do produtor, por meio da Diretiva 85/374/CEE, influenciaram diretamente a disciplina legal da mesma matéria nos países do Mercosul. O primeiro país a seguir o modelo foi o Brasil.

\subsection{O Código Brasileiro como Paradigma}

A preocupação internacional com a proteção ao consumidor coincidiu com o momento histórico da abertura política no Brasil e a instalação de uma Assembléia Constituinte. É bem nítida a linha cronológica que revela o nexo das influências políticas que fizeram com que o cons-
${ }^{63}$ “Art. $3^{\circ}$, 2. Sem prejuízo da responsabilidade do produtor, qualquer pessoa que importe um produto na Comunidade tendo em vista uma venda, locação, locação financeira ou qualquer outra forma de distribuição no âmbito de sua actividade comercial, será considerada como produtor do mesmo, na acepção da presente directiva, e responsável nos mesmos termos que o produtor".

${ }^{64}$ "Art. $3^{\circ}, 3$. Quando não puder ser identificado o produtor do produto, cada fornecedor será considerado como produtor, salvo se indicar ao lesado, num prazo razoável, a identidade do produtor ou daquele que lhe forneceu o produto. O mesmo se aplica no caso de um produto importado, se este produto não indicar o nome do importador referido no $\mathrm{n}^{\circ} 2$, mesmo se for indicado o nome do produtor". A denúncia do fabricante pelo fornecedor imediato em "prazo razoável" de certo não é boa inspiração, permitindo interpretações no sentido de uma cadeia de

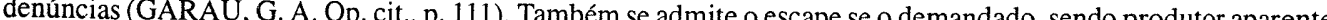
provar que o defeito é da matéria-prima ou de uma peça incorporada (BERCOVITZ, Alberto y BERCOVITZ Rodrigo Estúdios Juridicos sobre Proteción de los Consumidors Madid: TeChos, 1987. p. 267 Rodrigo. Estúdios Jurídicos sobre Protección de los Consumidores. Madrid: Tecnos, 1987. p. 267, interpretando 0 art. $3^{\circ}$, da Diretiva).

${ }^{65}$ "Art. $2^{\circ}$. Para efeitos do disposto na presente directiva, entende-se por 'produto' qualquer bem móvel, mesmo se incorporado noutro bem móvel ou imóvel. A palavra 'produto' designa igualmente a electricidade"

66 "Art. $4^{\circ}$. Cabe ao lesado a prova do dano, do defeito e do nexo causal entre o defeito e o dano". 
tituinte brasileiro implantasse em dois importantes sítios constitucionais a defesa do consumidor.

A necessidade de cooperação internacional na reconstrução da Europa no pós-guerra e a natural expansão dos mercados no regime capitalista ditou a conveniência da criação de organismos internacionais voltados para a conjugação de esforços e políticas com objetivos comuns.

A primeira organização a surgir foi a OECE (Organização Européia de Cooperação Econômica), fundada em 1948, pelos países aceitantes da oferta de ajuda norte-americana através do Plano Marshall.

Em 1968, a OECE foi sucedida pela OCDE Organização de Cooperação e Desenvolvimento Econômico), integrada pelos países europeus signatários da primeira convenção, mais os Estados Unidos e o Canadá, em virtude dos interesses comerciais comuns. Mais tarde associaram-se o Japão, a Austrália e a Nova Zelândia.

Foi nesse quadro que se desenvolveu a idéia de uma proteção sistemática ao consumidor, através da implementação de políticas que levassem em conta a sua situação de vulnerabilidade no mercado.

Em 1969 a OCDE criou a Comissão para a Política dos Consumidores, cujo trabalhou culminou em 1973 com a divulgação da Carta do Consumidor, através de Resolução do Conselho da Europa. Essa Carta lançou os direitos básicos dos consumidores, que receberam consagração universal na Resolução 39/248, de 10 de abril de 1985, da Organização das Nações Unidas. Logo três anos depois, foi promulgada a Constituição brasileira.

A defesa do consumidor é dever do Estado e direito subjetivo público de todo cidadão brasileiro, porque inserida no título das

garantias fundamentais, no capítulo dos direitos individuais e coletivos (art. $5^{\circ}$, inciso XXXII). Por outro lado, é um dos princípios que estrutura a ordem econômica, fator de moderação da livre iniciativa (art. 170, inciso V, CF).

Cumprindo disposição transitória (art. 48, do ADCT), o legislador ordinário elaborou a Lei $n^{\circ} 8.078$, de 11/9/90, que deu forma ao Código de Defesa do Consumidor.

\subsubsection{A Regência dos Princípios}

O Código de Defesa do Consumidor é uma conjugação de princípios, articulados por cláusulas gerais e conceitos jurídicos indeterminados, dando ao aplicador a possibilidade de subsumir nas disposições legais a inacabável diversidade de situações fáticas que se passa no âmbito abstrato de transações que faz a mediação de interesses e necessidades com os bens e serviços aptos ao seu atendimento: o mercado.

Para uma conveniente mediação, não é bastante uma lei como obra posta e definitiva A dinâmica do mercado exige atenção permanente. Por isso, a proteção ao consumidor é objeto de uma política nacional continuada, que tem como pressuposto a vulnerabilidade do consumidor (art. $4^{\circ}, \mathrm{I}, \mathrm{CDC}$ ).

Vulnerabilidade é exposição a um risco. Os consumidores são naturalmente vulneráveis, porque são heterogêneos e pouco coesos. Raramente se associam para defender coletivamente os seus interesses. Já os fornecedores são corporativos, mesmo quando atuam autonomamente (os profissionais liberais, por exemplo), sendo que na maioria das vezes a organização é imposta pela racionalidade e até pela lei (as sociedades comerciais). Daí a existência de uma "debilidade estrutural" no mercado em detrimento dos consumidores. ${ }^{67}$

${ }^{67}$ LORENZETTI, R. L. Fundamentos do Direito Privado. São Paulo: Revista dos Tribunais, 1998. p. 141. Revista da Faculdade de Direito da UFRGS, v. 20, Outubro/200I
Segundo Cláudia LIMA MARQUES, existem três tipos de vulnerabilidade: a técnica, a jurídica e a fática. ${ }^{68} \mathrm{Na}$ vulnerabilidade técnica, o consumidor é passível de engano porque não possui conhecimentos específicos sobre o objeto do consumo. Na vulnerabilidade jurídica, o consumidor sujeita-se especialmente às cláusulas abusivas dos contratos de adesão. $\mathrm{Na}$ vulnerabilidade fática, o consumidor pode ser vítima de abusos do poder econômico, como acontece no domínio de mercados através de monopólios, oligopólios ou cartéis.

Cumpre ao direito compensar a vulnerabilidade dos consumidores, através de mecanismos jurídicos de equilíbrio das desigualdades materiais. Assim: o juiz pode inverter o ônus da prova como meio de facilitar a defesa de direitos do consumidor (art. $8^{\circ}$, VIII); o juï deve interpretar os contratos de maneira mais favorável ao consumidor (art. 47); nos contratos realizados fora dos estabelecimentos comerciais, o consumidor tem direito de desistência imotivada (art. 49); os contratos só obrigarão os consumidores se lhes for dado conhecimento prévio do seu conteúdo e estiverem redigidos de modo compreensível (artigos 46 e 54, 8 $2^{\circ}$ ); as cláusulas consideradas abusivas são nulas de pleno direito, mas não invalidam o contrato, que deve ser preservado como meio de assegurar o atendimento das necessidades e interesses dos consumidores (art. 51 e parágrafo $2^{\circ}$ ); nos contratos de adesão, o direito de resolução é alternativa do consumidor (art. 54, $\S 2^{\circ}$ ); a defesa dos interesses e direitos dos consumidores pode ser realizada em juízo individual ou coletivamente (artigos 81 e 82) etc.

De um lado, mecanismos compensatóri-

os servem para atenuar a vulnerabilidade do mais fraco. De outro lado, ao mais forte são carregados deveres pré-contratuais e póscontratuais. $\mathrm{O}$ fabricante tem o dever de informar sobre os riscos e usos dos seus produtos (artigos $8^{\circ}$ e $9^{\circ}$ ) e deve assegurar a oferta de componentes e peças de reposição por tempo razoável, mesmo depois de cassada a produção (art. 32 e parágrafo único). A obrigação do fornecedor não depende, porém, de contrato, nascendo já da oferta (art. 30), que é suficiente para armar o consumidor de pretensão ao cumprimento forçado (art. 35, I).

As normas protetivas não devem instaurar, contudo, um espírito de antagonismo entre fornecedores e consumidores, que em verdade são pólos reciprocamente dependentes. A política nacional das relações de consumo visa a harmonia e o equilíbrio dos interesses em causa, procurando compatibilizar a proteção legal com o desenvolvimento econômico e tecnológico, tal como propõe o art. $4^{\circ}$, inciso III, do CDC. A relação de consumo, independentemente da existência de contrato, é uma totalidade, que convoca entre fornecedores consumidores uma ordem de cooperação, ${ }^{69}$ cuja base é a boa-fé.

A boa-fé, neste caso, é uma mediação entre princípios tensionais e estruturais da or dem econômica, quais sejam, a livre iniciativa e a defesa do consumidor (art. 170, incisos IV e V, $\mathrm{CF}$ ). A ordem ẹconômica se sobrepõe à autonomia privada, refreando o poder econômico, ao mesmo tempo em que ultrapassa a simples defesa do débil, olhando ao interesse social privilegiando a coletividade de consumidores. ${ }^{70}$ Retomando a idéia de LORENZETTI, a boa-fé

${ }^{68}$ LIMA MARQUES, C. Contratos no Código de Defesa do Consumidor. $3^{a}$ ed. São Paulo: Revista dos Tribunais, 1999. p. 147.

${ }^{69} \mathrm{O}$ conceito de totalidade obrigacional, vem exposto na valiosa introdução d' A Obrigação como Processo, de Clóvis do COUTO E SILVA (São Paulo: Bushatsky, 1976).

${ }^{70}$ AGUIAR JÚNIOR, R. R. A boa-fé na relação de consumo. Direito do Consumidor, São Paulo, v. 14, p. 21 ss. 
concilia os fatores estruturais do mercado, ainda que em eventual detrimento de interesses conjunturais. Daí o pertinente exemplo dos consórcios para aquisição de bens duráveis mencionado por Ruy Rosado de AGUIAR. A devolução das prestações pagas ao desistente só deve ser feita no final do plano, para não prejudicar os demais consorciados. ${ }^{7}$

\subsubsection{Produção e Responsabiliadade}

A atividade industrial não constitui um fator autônomo de responsabilidade. ${ }^{72}$ Ela é socialmente útil e necessária ao desenvolvimento econômico. A razão de ser da responsabilidade do fabricante está no defeito dos produtos. ${ }^{73}$ É impossível uma produção isenta de defeito, dada a falibilidade humana. $\mathrm{O}$ risco assumido pelo produtor é a eventualidade do defeito, ainda que involuntário. A responsabilidade industrial funda-se, portanto, num risco - risco que não está para o dano, mas para o defeito. O dano conseqüência que nem sempre se materializa. $O$ defeito constitui ameaça geral. O dano é prejuízo particular trazido à vítima pelo acidente. Havendo defeito sem dano, o bem jurídico em causa é a segurança dos consumidores e como conseqüência o produto deve ser retirado do mercado. É uma fase de prevenção. ${ }^{74} \mathrm{Se}$ ocorrer o dano terá que haver a reparação, desde que se constate o defeito.

3.1.2.1. Condiç̃es da responsabilidade civil do fabricante. O dano provém do chamado fato do produto.

Fato do produto é o acidente, acontecimento em cuja avaliação jurídica não se levam em conta fatores de voluntariedade ou previsibilidade. O evento danoso é considerado a partir da sua própria realidade e visto como um elemento de injustiça para a vítima. $\mathrm{Na}$ sociedade industrial tais acidentes são, lamentavelmente, inevitáveis. Por mais aperfeiçoados que se tornem os processos produtivos, jamais conseguirão reduzir a zero o risco de defeitos. Não se pode, porém, condicionar a reparação dos prejuízos à identificação de um culpado. A divisão do trabalho e a automação industrial concorreram para tornar os agentes humanos da produção praticamente anônimos. Dessa sorte, na disciplina dessa matéria o direito não olha mais para a ação dos homens ${ }^{75}$ e sim para o fato das coisas. Não há mais lugar para a culpa como fator de imputação da obrigação reparatória. Sucedeu-a o risco que o fabricante cria para terceiros ao colocar em circulação produtos defectíveis. O risco socialmente suportável é limitado ao que é inerente à utilização normal do produto, sendo alocado ao fabricante o perigo agregado por imperfeição do processo industrial.

O defeito é a relação causal entre o acidente (fato) e o resultado lesivo. É presumido o

${ }^{11}$ Op. cit., p. 22

${ }^{72}$ Nesse sentido uma conclusão das XV Jornadas Nacionales de Derecho Civil, de Mar del Plata (Argentina), 26 28 out. 95 , comissão n. 2, sobre Responsabilidade Civil pela Atividade Industrial, com presidência de Atílio Alterini e Roberto López Cabana, coordenação de Ricardo Lorenzetti e Silvia Tanzi. In Derecho Del Consumidor. Buenos Aires: Juris, n. 7, 1996. p. 123.

${ }^{73}$ A jurisprudência norte-americana, depois "flertar" nos anos 80 com uma responsabilidade do fabricante sem defeito do produto, refluiu para o sistema do defeito. HENDERSON JR. e TWERSKI, op. cit., p. 1271

${ }^{74}$ JOERGES, C. (Le 'Consumer Product Safety Act' americain et sa mise en oeuvre par la 'Consumer Product Safety Comiscion. Revue Internationale de Droit Comparé, n. 1,40. année, p. 7-37, jan.-mars 1988) critica a ausência de regras voltadas à prevenção dos danos na Europa, em contraste com os Estados Unidos.

a ausência de regras voltadas à prevenção dos danos na Europa, em contraste con
${ }^{75}$ Código Civil. "Art. 159. Aquele que, por ação ou omissão voluntária...". defeito, uma vez que incumbe ao fornecedo provar a sua inexistência (art. 12, parágrafo $3^{\circ}$, II, do CDC). Dado que o fabricante não pode colocar em circulação produtos inseguros (art. $8^{\circ}$ ), a ocorrência de um dano autoriza a presunção.

A pedra de toque da responsabilidade civil do fabricante é o defeito do produto, seja para prevenir, seja para reparar. O dano é pressuposto da indenização, não da responsabilidade. Pode haver responsabilidade sem dano, sendo obrigação retirar o produto defeituoso do mercado para afastar o perigo.

A política de prevenção de acidentes no CDC resume-se a um controle de comercialização e pós-comercialização, resolvendo-se basicamente num dever de informar positivado a partir da boafé. A inspiração do legislador nacional certamente foi o Consumer Product Safety Act, de 1972, que estabelece um amplo controle sobre a qualidade dos produtos, inclusive com um banco de dados sobre a ocorrência de acidentes, que serve para o desenvolvimento de novos mecanismos de segurança. ${ }^{76}$

Os fabricantes devem informar os consumidores sobre os usos normais e os riscos que dos seus produtos. Um produto não deve expor ninguém a risco maior do que o normal e previsível, de acordo com a sua natureza e modo de fruição. Têm os fornecedores um dever de segurança frente aos consumidores. Não é aceitável mais do que a periculosidade inerente ao bem, sem risco adicionado no processo produtivo (periculosidade adquirida). ${ }^{77} \mathrm{O}$ art. $8^{\circ}, \mathrm{CDC}$, ao dispor nesse sentido, exibe a matriz do fator de imputação da responsabilidade civil do for- necedor por produtos defeituosos.

A informação deve acompanhar os produtos industriais e ser prestada de modo mais ostensivo ou menos, conforme o grau de periculosidade.

O fabricante deve controlar o processo industrial, incumbindo-lhe conhecer todas as inovações pertinentes e manter o produto tecnologicamente atualizado em matéria de segurança. Se a periculosidade só é percebida depois que o produto está em circulação, as autoridades e os consumidores devem ser prontamente comunicados, e feita a substituição do bem ou dos componentes defeituosos. A obediência a tal regra vulgarizou o recall.

O plano da prevenção procura resguardar a segurança dos consumidores, sendo precisamente este o bem jurídico tutelado. Já no plano da reparação, trata-se de proteger a integridade física e psíquica dos consumidores.

Todavia, não se haveria de negar indenização ao bystander que sofresse prejuízo apenas econômico em conseqüência de um acidente de consumo. ${ }^{78}$ Imagine-se um automóvel estacionado próximo a um posto de gasolina, atingido pela explosão de uma das bombas de abastecimento. Caracterizando-se o acidente de consumo, não seria razoável remeter o proprietário às regras da responsabilidade civil comum, discriminando-o dentre as vítimas, apesar de não estar explicitada essa situação na lei brasileira. A Diretiva da Comunidade Européia manda indenizar a morte ou lesões corporais e os danos causados a uma coisa ou a destruição de uma coisa $\left(\operatorname{art} .9^{\circ}\right) .79$

${ }^{76}$ JOERGES, C. Ob. cit.

${ }^{77}$ Things dangerous "per se" (ou things inherently dangerous) e things dangerous because of negligent construction, distinguidas no direito inglês e no direito norte-americano. Cf. supra.

${ }^{78}$ Danos indiretos (consequential damages) do direito inglês. Cf. supra (A-I).

${ }^{79}$ STIGLITZ, G (El derecho del consumidor en Argentina y en el Mercosur. La Lei, Buenos Aires, 19 mayo 1995 , p. 1-5) classifica os danos ao consumidor em intrínsecos (sofridos apenas no próprio produto adquirido) extrínsecos (sofrido pelo consumidor em sua pessoa ou em seus outros bens). 
A responsabilidade civil do fabricante não se funda mais em culpa pelo dano da vítima, mas no risco de que o produto tenha defeito e cause dano a alguém. A lei imputa-lhe o risco, mas não em sentido integral ou absoluto, porque não o relaciona com o só fabricar o produto, mas sim com a existência de defeito.

Três situações a lei admite em que não é devida indenização, ainda que o consumido algum dano sofra: a) se o fornecedor demandado não colocou em circulação o produto causador do dano (v.g., se o produto é falsificado); b) se o produto não é portador de defeito, sendo provavelmente outra a causa do dano; c) se houve culpa exclusiva da vítima ou de terceiro. As três situações referem-se ao nexo causal, inclusive a terceira, onde a palavra culpa está em lugar de "fato".

A segunda excludente não deixa dúvida sobre ser o defeito nexo causal da responsabilidade do fornecedor pelo fato do produto. $\mathrm{O}$ dano terá havido em razão do produto, mas sem que se constate defeito. Vale lembrar que defeito é déficit de segurança. Poderá haver, por exemplo, uso inadequado do produto, sem defeito de informação. Imagine-se automedicação de paciente portador de contraindicação especificamente advertida na bula.

$\mathrm{Na}$ terceira excludente, para que o fornecedor se livre, o fato do consumidor ou de terceiro deve ser exclusivo, sem coexistência

${ }^{80}$ Aceitando: MARINS, J. (Responsabilidade da empresa pelo fato do produto. São Paulo: Revista do ${ }^{80}$ Aceitando: MARINS, J. (Responsabilidade da empresa pelo fato do produto. São Paulo: Revista dos
Tribunais, 1993), que considera juridicamente irrelevantes os defeitos decorrentes de culpa exclusiva da vítima ou de terceiro, caso fortuito, força maior, riscos do desenvolvimento eça do plo fato do produto no direito

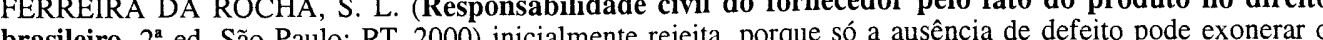
brasileiro. 2 ad. Sa Paus defricante, mas admite que caso fortio brasileiro de defesa do

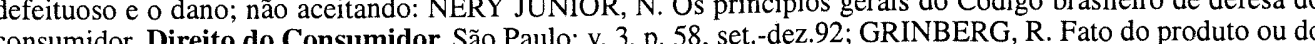

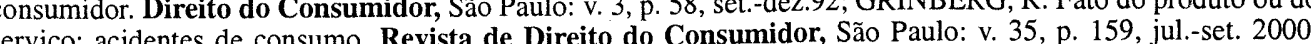
LIMA LOPES, J. R. (Responsabilidade civil do fabricante e a defesa do consumidor. São Paulo: RT, 1992 situa a responsabilidade civil do fabricante na dialética do capitalismo (op. cit., p. 151), justificando-se a situa a responsabilidade civil do fabricante na dialetica io cável a falha no processo produtivo, restando ao fabricante a única alternativa de provar a inexistência do defeito (op. cit., p. 76).

${ }^{81}$ LORENZETTI, R. L. Fundamentos do Direito Privado. São Paulo: Revista dos Tribunais, 1998. p. 226.

Revista da Faculdade de Direito da UFRGS, v. 20, Outubro/2001
De um lado, o fabricante tem melhores condições de suportar os danos causados aos consumidores, porque pode prevenir o desembolso da indenização, repartindo previamente esses custos e agregando-os ao preço do produto. Assim fica excluída a necessidade de levar em conta a culpa pela existência do defeito como fator de imputação da obrigação de indenizar. O fabricante responde pelo risco do defeito e danos eventuais. Também pode transferir esse risco contratando um seguro de responsabilidade civil, cujo prêmio será considerado um custo financeiro da produção.

De outro lado, a inadvertida circulação de produtos defeituosos pode realizar o lucro do fabricante. Nem todos os produtos defeituosos causam danos aos consumidores e nem sempre os lesados reclamam as correspondentes indenizações. É justo, pois, que os fabricantes indenizem os consumidores sempre que os defeitos dos seus produtos lhes causarem dano, sem possibilidade que invoquem como eximente qualquer fator causal incluído no espectro do risco da produção. Isso exclui, de plano, o caso fortuito, concebido como "um impedimento relacionado com a pessoa do devedor ou com a sua empresa", sendo aceitável apenas a idéia de força maior, um "caso fortuito externo". ${ }^{82}$

O mesmo pode ser dito quanto aos riscos do desenvolvimento, provavelmente com maior razão ainda, posto que certos riscos são assumidos de modo consciente pelo fabricante. Basta pensar nas controvérsias a respeito

de possíveis malefícios decorrentes de produtos alimentares transgênicos e da radiação dos telefones celulares e dos fornos de microondas. Nada obstante, ignorando eventuais efeitos perversos, as empresas desenvolvem as suas atividades face à inexistência de proibições, com fundamento na liberdade econômica. É evidente que, comprovando-se no futuro algum malefício, terão que arcar com as indenizações correspondentes, porque arrostaram o risco da existência de defeito.

Na Diretiva européia os riscos do desenvolvimento são causa de exclusão da responsabilidade do produtor ${ }^{83}$, mas foi ressalvada a derrogação da regra pelos estados membros.$^{84} \mathrm{~A}$ ressalva foi introduzida por instância da França, cuja jurisprudência não exclui a responsabilidade do fabricante em caso de vício oculto que afete a utilidade do produto, apesar de não ser igualmente protegida a segurança do consumidor ${ }^{85} \mathrm{Na}$ transposição da diretiva, apenas Luxemburgo e Finlândia derrogaram completamente a excludente no seu direito interno. A Espanha excepcionou o regime comunitário apenas para medicamentos, alimentos e produtos alimentícios de consumo humano. A lei alemã de 15/12/89 manteve-se fiel à diretiva, mas lei especial de 20/6/90, com modificações de 1933 e 1994, não acata a excludente para produtos transgênicos. O Reino Unido introduziu regime mais liberal do que a diretiva, admitindo a exclusão de responsabilidade do produtor cujos conhecimentos científicos e técnicos não

${ }^{82}$ ALVIM, A. Da inexecução das obrigações e suas conseqüências. São Paulo: Saraiva, 1949. p. 290. 83 “Art. $7^{\circ}$. O produtor não é responsável nos termos da presente directiva se provar: (...) e) Que o estado dos conhecimentos científicos e técnicos no momento da colocação circulação do produto pelo produtor não permitiu detectar a existência do defeito".

84 “Art. $15^{\circ}$. Qualquer Estado-membro pode: (...) b) Em derrogação da alínea "e" do artigo $7^{\circ}$, manter ou (...) prever na sua legislação que o produtor é responsável, mesmo se este provar que o estado dos conhecimentos científicos e técnicos no momento da colocação do produto em circulação não lhe permitia detectar a existência do defeito".

${ }^{85}$ VINEY, G. La responsabilité..., op. cit., p. 590, que exemplifica a restrição jurisprudencial com decisão da Corte de Cassação, datada de 8/4/86, que desestimou caso de infecção provocada pela combinação de dois medicamentos.

Revista da Faculdade de Direito da UFRGS, v. 20, Outubro/2001 
permitisse ao fabricante de um produto análogo detectar o defeito do produto no momento do seu lançamento no mercado. A Comissão das Comunidades Européias interpretou a norma britânica, integrada ao Consumer Protection $A c t$, como contrária à diretiva, por incluir um elemento de subjetividade, ou seja, os conhecimentos de outro produtor supostamente diligente. ${ }^{86}$ A Corte de Justiça das Comunidades Européias pronunciou-se sobre a questão em 29/5/97, decidindo que "um produtor somente se liberará da responsabilidade pelo fato dos seus produtos defeituosos se o estado dos conhecimentos científicos e técnicos no momento da colocação dos produtos no mercado não lhe permitissem descobrir a existência do defeito", recaindo a carga da prova exoneratória sobre o próprio produtor

3.1.2.2. Devedor da indenização. $O$ legislador brasileiro optou por nomear os sujeitos passivos da obrigação de indenizar os danos decorrentes de defeitos: o fabricante (de manufaturas acabadas ou de componentes), o produtor (de alimentos, in natura ou industrializados; de medicamentos), o construtor (de obras civis) e o importador (de quaisquer produtos). A responsabilidade é imputada a quem coloca o produto no mercado. ${ }^{87} \mathrm{~A}$ responsabilidade dos fabricantes de peças componentes está expressa no art. 25, parágrafo $2^{\circ}$. Subsidiariamente também responsável o comerciante. Trata-se de imposição da lógica, pois o comerciante, geralmente, não tem o controle do produto, que recebe acabado, repassando-o no mesmo estado ao consumidor.

${ }^{86}$ GARCÍA RUBIO, M. P. Los riesgos de desarrollo en la responsabilidad por daños causados por productos defectuosos: su impacto en el derecho español. Revista de Direito do Consumidor, São Paulo: v. 30, p. 66-84, abr.-jun. 99.

${ }^{87}$ BENJAmin, A. (Comentários ao Código de Proteção ao Consumidor. OLIVEIRA, J. (coord.). São Paulo: Saraiva, 1991. p. 56) classifica os fornecedores, nesse caso, em responsáveis reais (fabricante, produtor e construtor), presumido (importador) e aparente (comerciante).

${ }^{88} \mathrm{~V}$., adiante, parte II-B.

Revista da Faculdade de Direito da UFRGS, v. 20, Outubro/2001

O comerciante só será demandado se os responsáveis principais não puderem ser identificados ou se o produto não contiver a identificação clara do fornecedor primário. Falta menção expressa, na lei brasileira, ao fabricante aparente. É comum que redes de varejo ofereçam diversificada linha de produtos com sua própria marca, como se fabricantes fossem. Em vervarejista, por um terceiro que permanece oculto. Nesses casos, o comerciante poderá ser responsabilizado, pois o fabricante age como seu preposto $^{88}$, sem prejuízo de eventual ação contra este, em razão da solidariedade estabelecida no art. $7^{\circ}$, parágrafo único.

O comerciante também será responsabilizado quando não conservar adequadamente produtos perecíveis.

Por comerciante não se compreenderá tãosomente o último elo da cadeia de fornecimento - 0 varejista - mas toda a cadeia de intermediários, incluindo, pois, atacadistas e distribuidores.

\subsection{Os Parceiros do Mercosul}

Ainda não há normas comunitárias de proteção ao consumidor no Mercosul, permanecendo em vigor a Resolução 126/94, do Grupo Mercado Comum, dispondo que cada Estado parte aplique a sua legislação nacional enquanto não seja aprovado um regulamento comum. Os esforços nesse sentido fracassaram e as dificuldades atuais do Mercosul pela heterogeneidade de políticas econômicas dos países que o integram deixam em compasso de espera a continuidade dos trabalhos. dade, o produto é fabricado, a pedido da rede

3.2.1. Convergências da Legislação Interna dos Países Membros do Mercosul sobre Produtos Defeituosos

A lei argentina (Lei 24.240, sancionada em 22/9/93 e publicada definitivamente em $15 / 10 / 93$ ) dedica o segundo capítulo do primeiro dos seus três títulos à informação do consumidor e proteção de sua saúde, impondo a todos que produzam, importem, distribuam ou comercializem coisas o dever de prestar, com objetividade, informação verdadeira, detalhada, eficaz e suficiente sobre suas características essenciais. Os produtos, utilizados em condições normais ou previsíveis, não podem apresentar perigo para a saúde ou a integridade física dos consumidores, instituindo uma obrigação de segurança para os fabricantes. Se o produto envolve riscos de uso devem ser observiadas as normas estabelecidas ou as razoáveis para garantia da segurança dos consumidores.

Essas disposições voltam-se para a prevenção de danos. A reparação é prevista no art. 40, com redação modificada pela Lei 24.999 , de 1998. São obrigados a indenizar os danos o produtor, o fabricante, o importador, o distribuidor, o fornecedor, o vendedor e quem quer tenha aposto sua marca ao produto (produtor ou fabricante aparente). São todos devedores solidários, sendo permitida, porém, a prova de causa estranha à atuação do demandado. O transportador responderá pelos danos causados pelo seu serviço. A lei é omissa quanto ao fator de imputação da responsabilidade, mas a jurisprudência do Código Civil nessa matéria, relativa à aplicação do art. 1.113, com a redação da Lei 17.711, de 1968, é compatível com a imputação objetiva. O dono ou guardião é responsável pelo fato causado por vício ou risco inerente à coisa, podendo livrar-se somente se houver culpa exclusiva da vítima ou de um ter-

ceiro por quem não deva responder, incumbindo-lhe o ônus da prova. ${ }^{89}$

A falta de uma lista de direitos básicos na lei ordinária foi suprida pela reforma, em 1994 da Constituição nacional da Argentina, que passou a prever, no seu art. 42 , o direito dos consumidores e usuários de bens e de serviços à proteção da sua saúde, segurança e interesses econômicos, dentre outros.

A lei uruguaia (Lei $\mathrm{n}^{\circ} 17.189$, promulgada em setembro de 1999 para entrar em vigor nove meses depois) compreende quinze capítulos, dedicando o segundo aos direitos básicos do consumidor, o terceiro à proteção da saúde e segurança e o décimo terceiro à responsabilidade por danos.

Os direitos básicos compreendem, dentre outros, a proteção da vida, da saúde, da saú de e da segurança contra os riscos causados pelas práticas no fornecimento de produtos e serviços considerados perigosos ou nocivos.

Os riscos normais devem ser prevenidos pela observância das normas estabelecidas ou conforme as que forem razoáveis, na esteira da fórmula argentina. No fornecimento de produtos perigosos deve haver informação clara e visível sobre a periculosidade ou nocividade. Em caráter excepcional e fundamentadamente, a administração pode proibir a colocação no mercado de produtos de alto risco. Indo além do marco lei argentino, a lei uruguaia prevê o recall dos produtos cuja periculosidade seja detectada após a sua introdução no mercado.

A responsabilidade pela reparação de danos é remetida ao regime geral do Código Civil. Em regra análoga ao CDC brasileiro, são devedores da indenização o fabricante ou o importador, só respondendo o comerciante quando aqueles não puderem ser identificados ou

${ }^{89}$ ALTERINI, A. A. Responsabilidad civil. 3. ed. Buenos Aires; Abeledo Perrot, 1992. p. 115-121. No mesmo sentido, STIGLITZ, G, que menciona decisões pretorianas sob a Lei 24.240 aplicando regime de responsabilidade objetiva ao fabricante (Modificaciones..., ob. cit.). 
quando este não conservar adequadamente o produto ou alterar suas condições originais. $\mathrm{O}$ dano é caracterizado como fato ilícito e limitado às suas conseqüências diretas e imediatas, de ordem patrimonial ou extrapatrimonial. midor e do Usuário (Lei 1.334) é de 1998 e está disposta em quinze capítulos, sendo o segundo de direitos básicos e o sétimo de proteção à saúde e segurança. vida, da saúde e da segurança começa pelo dever de informar sobre a periculosidade ou nocividade dos produtos e serviços, sendo previsto o recall para os riscos conhecidos com posteridade ao lançamento no mercado. A le silencia quanto ao regime da responsabilidade dos fornecedores na reparação de danos.

\subsubsection{Entraves à criação de uma Lei Supranacional de Defesa do Consumidor} mes no Mercosul encontra o óbice estrutura da ausência de uma verdadeira supranacionalidade no processo de integração, uma vez que o Tratado de Assunção (1991) não transfere competências dos países soberanos para órgãos comunitários, havendo mesmo empecilhos constitucionais a serem previamente removidos, inclusive no Brasil. Nada obstante, há organismos que cuidam da formulação de regras para setores específicos, como é o caso do Comitê Técnico $\mathrm{n}^{\circ}$ 7, da Comissão de Comércio, criada pelo Protocolo de Ouro Preto (1994), que complementou o Tratado de Assunção. O CT 7 dedica-se à defesa do consumidor. É
No Paraguai, a Lei de Defesa do Consu-

A efetividade do direito à proteção da

A introdução de regras jurídicas unifor-

questionável, porém, a sua legitimidade, porquanto os seus integrantes, em verdade, são delegados do Poder Executivo dos países membros, pois a Comissão de Comércio é vinculada ao Grupo Mercado Comum, órgão executivo do Mercosul, integrado por representantes dos respectivos governos. Os direitos do consumidor, sendo direitos humanos de terceira geração e estando previstos como direitos fundamentais na Constituição (de Argentina e Brasil), só poderiam ser regulados através de tratados internacionais e não por decisão interna de órgãos subalternos do Mercosul, por falta da competência legislativa supranacional..$^{90}$

Apesar de tudo, em 1997 foi elaborado um projeto de Protocolo Comum de Defesa do Consumidor, no âmbito do CT 7, cuja aprovação implicaria a derrogação de 26 normas do Código brasileiro, em verdadeiro retrocesso para um pretenso nivelamento das diferentes leis nacionais. O projeto só não restou aprovado por desistência de última hora do governo brasileiro, a instâncias das entidades envolvidas com a política e os direitos do consumidor

$\mathrm{O}$ que realmente atenderia o interesse dos consumidores no Mercosul seria a harmonização das legislações existentes, com a criação de patamares básicos de proteção, sem prejuízo de níveis mais altos estabelecidos in ternamente em cada país membro. A proteção básica não poderia ficar abaixo do padrão internacional, haja vista o patrimônio universal que ao longo do tempo foi formando-se na jurisprudência dos países industrializados.

A harmonização deve preocupar-se particularmente com a compatibilidade dos princí

${ }^{90}$ LIMA MARQUES, C. Regulamento comum de defesa do consumidor do Mercosul: primeiras observações sobre - Mercosul como legislador da proteção do consumidor. Direito do Consumidor, São Paulo, n. 22-23, p. 79 103, jul.-dez. 97. Direitodo Consmidor, São Paulo, n.32, p. 16-44, out.-dez. 99. no plano nacional. ${ }^{91}$

${ }^{91}$ LIMA MARQUES, C. Direitos do consumidor no Mercosul: algumas sugestões frente ao impasse. Revista de

Revista da Faculdade de Direito da UFRGS, v. 20, Outubro/2001 pios e não tanto com a coincidência das regras. Todas as leis têm um conjunto de direitos básicos (no caso da Argentina, presente na Constituição), que inclui: proteção da vida, da saúde e da segurança, com responsabilidade pela repacia de culpa; garantia absoluta contra vícios que afetem a utilidade dos produtos e serviços, com vedação de exonerações contratuais; proteção contratual, especialmente nos contratos de adesão e contra práticas abusivas; proteção contra abusos da publicidade; vinculação obrigacional da oferta e garantias de cumprimento; tutela coletiva de direitos. Também existem mecanismos comuns de facilitação da defesa dos direitos do consumidor, como a inversão do ônus da prova; a interpretação mais favorável ao consumidor das normas das relações de consumo; a hierarquia indisponível das regras protetivas, porque pertencentes à ordem pública; a não taxatividade dos direitos dispostos nas leis e a sua integração por outros direitos, derivados de fontes diversificadas.

Todavia, não é suficiente a existência de textos legislativos satisfatórios. As leis podem ser importadas, mas não a sua implementação, anota Gabriel STIGLITZ, apontando como causas das deficiências de aplicação dos sistemas de proteção ao consumidor na América do Sul o desinteresse dos governos e o insignificante papel atribuído à questão no processo de integração do Mercosul. ${ }^{92}$

A incongruência de alguns vetos impostos a artigos do Código brasileiro e da lei argentina ${ }^{93}$ denunciam a subordinação dos governos a forças que só encontram explicação coerente na pressão a que se submetem quando se trata de disciplinar as atividades econômicas. ${ }^{94}$ Freqüentemente também sobressai o pouco apreço que nutrem pelos avanços legislativos, vendo-os mais como discurso político-e, portanto, conforme a sua prática, a qualquer momento revogável - do que como marco regulatório. Repetiu-se recentemente no Brasil a tragicomédia da derrogação de uma lei geral frente a um fato circunstancial, quando imperial medida "provisória" procurou afastar a aplicação do Código de Defesa do Consumidor nas eventuais decisões judiciais que versassem sobre a crise de energia elétrica.

O desinteresse dos governos ainda é lamentavelmente testemunhado no Brasil pelo descaso com que as administrações tratam os consumidores. É pequena a proporção de municípios que contam com um Procon, encontrando-se entre os omissos capitais importantes como Porto Alegre, não obstante os três mandatos consecutivos de governos de esquerda que coincidem com o decênio de vigência do Código de Defesa do Consumidor. Infelizmente, não é o único exemplo expressivo. ração de danos, independentemente da existên-

${ }^{92}$ STIGLITZ, G. El derecho del consumidor en Argentina y en el Mercosur. La Lei, Buenos Aires, 19 mayo 1995 p. 1-5.

${ }^{93} \mathrm{Na}$ Argentina, o Presidente da República vetou a redação original do artigo 40, da Lei 24.240, que dispunha sobre a responsabilidade objetiva dos fornecedores, apesar de haver projeto do Executivo em tramitação legislativa introduzindo regime mais rigoroso; o argumento do veto foi que o regime previsto era excessivamente gravoso para os produtores argentinos e mais severo do que o instituído no Código brasileiro, ignorando o conteúdo do art. 12, CDC (LOPEZ CABANA, R. M. Responsabilidade civil por la actividad industrial. Temas de derecho privado. Buenos Aires, n. 7, p. 18-23, 1995.

${ }^{94}$ No mesmo tom, STIGLITZ, G. Modificaciones a la Lei argentina de defensa del consumidor y su influencia en el Mercosur. Direito do Consumidor, São Paulo, n. 29, p. 9-20, jan.-mar. 99. 


\section{Conclusão}

A proteção contra produtos defeituosos é uma conquista universal do direito. Essa conquista é colocada à prova nos blocos econômicos. Em alianças fortes, como a União Européia, verifica-se uma integração de regimes jurídicos, com nivelação do regulamento comunitário acima dos patamares médios pré-existentes. Todavia, nos blocos mais fracos, como - Mercosul, a tentativa de harmonização das regras jurídicas embute o risco de um retrocesso para os países membros que lograram maio avanço legislativo interno. A nivelação pode ser feita por baixo, com a derrogação de leis e aviltamento da jurisprudência inovadora, garantidoras de uma proteção mais efetiva. A contínua concentração do poder econômico e a expansão transfronteiras dos mercados tornam mais do que nunca necessária a vigência de um regime jurídico favorável aos consumidores.

Os elementos em tensão nesse embate são, de um lado, os interesses dos consumidores e, de outro, as forças econômicas. Como estas são determinantes na formação dos blocos econômicos, elas tendem a prevalecer freqüentemente conseguem a adesão de governos dependentes de investimentos. Nessa con- tingência, os consumidores dependem, no plano do direito, da racionalidade jurídica, e no plano sociológico, de suas próprias iniciativas. A racionalidade jurídica pode oferecer resistência a mudanças legislativas oportunistas fazendo prevalecer os marcos avançados, especialmente se eles já estão fincados em território constitucional, como é o caso brasileiro. A defesa do consumidor, no Brasil, é direito subjetivo público de todo cidadão frente ao Estado, integrando o elenco dos direitos fundamentais (art. $5^{\circ}$, inciso XXXII), e princípio estrutural da ordem econômica (art. 170, inciso V,CF)

Os consumidores, por sua vez, devem organizar-se em associações, habilitando-se à defesa própria de seus interesses no plano coletivo, único nível em que se torna viável o enfrentamento do poder econômico no entrechoque de interesses que caracteriza o mercado. Essa providência, além de estimulante do ponto de vista do exercício dos direitos de cidadania, tornaria o consumidor menos dependente das iniciativas de órgãos oficias, tais como o Ministério Público e os Procons, revertendo o paternalismo em autonomia.

\section{La Posmodernidad juridica los derechos de las personas bajo la linea de indigencia los criterios de reciprocidad e igualdades razonables: documento de debate}

\author{
Carlos A. Ghersi
}

\section{Introducción}

17 xiste una concepción de equidad y justicia que se reclama constantemente para los incluidos, sin embargo, pareciera que no se aplica para aquellos que los propios gobiernos con la misma Constitución, no los consideran (para los marginados y excluidos) por no tener un rol sustancial en la sociedad, a pesar que poseen los mismos ideales y utopías reales.

En este sentido consideramos a estas personas como proscriptos o personas lastradas por condiciones desfavorables ${ }^{1}$, que por esta misma razón no pueden alcanzar el status de incluidos (algunos generacionalmente) y sobre los que pretendemos establecer las condiciones

mínimas que debieran poseer por el solo hecho de ser humanoides.

En realidad estas personas proscriptas o lastradas se encuentran especialmente afectadas por la injusticia de decisiones políticas, que debieran mantener la armonía de intereses y que sin embargo privilegian un sector minoritario de la sociedad, causando así la marginación y la pobreza denigrante ${ }^{2}$.

En este sentido de condiciones mínimas, sostenemos que básicamente deben considerar la posibilidad real de aplicar dos nuevos criterios que debieran asumir la calidad de principios generales del derecho: la reciprocidad $\mathrm{y}$ las igualdades razonables.

1. El término personas lastradas lo adopté y lo hice de John Rowls ( El derecho de Gentes Ed Paidos. Barcelona 2001 ) y que normalmente en la sociedad argentina se los atribuyó a marginados y desocupados, como procesos diferentes y de fragmentación interna de la comunidad. La marginación se constituye a partir de una cuestión social (aspecto sociológico ) como proceso de desintegración de pertenencia y denigración, en cambio la desocupación
(aspecto económico ) hace al proceso del sistema producción / consumo y la función económica del trabajo, ( sin duda que en general se presentan conjuntamente, pero insistimos no son conceptualmente sinónimos )

${ }^{2}$ Consult. Nochteef, Hugo y otros. La Economía argentina a fin de siglo: fragmentación presente y desarrollo ausente. Ed Flacso - EUDEBA . Bs As 1998.;

Filmus, Daniel. Los noventa. Politica, Sociedad y cultura en América Latina y Argentina de fin de siglo. Ed Flacso - EUDEBA, Bs As 1999.

Revista da Faculdade de Direito da UFRGS, v. 20, Outubro/2001 